\title{
4 \\ From objects to design programmes
}

Just as neodecorativism was generating the idea of a spiritually useful object, its leading proponent, Boris Smirnov, published his succinct Artist on the Nature of Things. ${ }^{1}$ Its title alludes to the first-century BCE poem De rerum natura by the Roman poet and philosopher Lucretius. In the book Smirnov discussed the traditions, techniques and symbolic meanings of the design of consumer objects. In essence, it was a work of professional self-reflection. Smirnov paid special attention to the emergence of a new object, which he described as

a complex creative-industrial [tvorcheski-proizvodstvennyi] process involving different specialists: scientists, engineers and artists. The artist's role in this process is very large. $\mathrm{He}^{2}$ devises at once an object itself and the way it can be used. An artist is a director [rezhisser] of the object's consumption; he organises the relationship between a user and an object and, on this basis, he defines its place and specificity among other objects, its consumer qualities. An artist should be broad-minded, cultured in his approach to a consumer object, whatever the purpose of this object is, and however small and insignificant it may seem. ${ }^{3}$

Although he used the term 'artist', Smirnov was in fact describing the work of a designer. His description bears a similarity to the statement of the First Congress of ICSID, held in Stockholm in 1959, which defined an industrial designer as 'one who is qualified by training, technical knowledge, experience and visual sensibility to determine the materials, mechanisms, shape, colour, surface finishes and decoration of objects...' ${ }^{4}$ Like the ICSID definition, Smirnov's passage refers to the process of defining the qualities of objects on the basis of broad knowledge.

There is, however, an important distinction between Smirnov's and the ICSID's definitions if we consider the ending of the latter: '.. objects, which are reproduced in quantity by industrial processes'. ${ }^{5}$ Smirnov does 
not specify any such scope or mode of production. His understanding of a consumer object includes both mass-produced and unique/limited-edition artefacts, such as, for example, his 'Tea Couple'. Even though Smirnov mentions industrial production in his book, what interests him most is not mass reproducibility, but the relationships between different consumer objects and between objects and their users. While theorists of productivism presented the artist as an organiser of both production and everyday life, ${ }^{6}$ Smirnov believed that the artist, though educated in technology, should delegate nuts-and-bolts questions to engineers and technicians and concentrate instead on foreseeing possible consumption scenarios. It is not by accident that he uses the term rezhisser - 'film or theatre director' - to describe the artist's role in improving consumer culture. His vision of the artist/designer directing consumption recalls a 1957 lecture by Aleksandr Chekalov regarding vibrancy in applied art: Chekalov argued that an applied artist must be responsible for 'the whole sphere of activity' related to an object. ${ }^{7}$ However, Smirnov, who combined the skills of a glass artist and a designer of optical tools, was definitely aware of the growing tendency of Soviet industrial designers (still called 'artist-engineers', khudozhniki-konstruktory) to think in terms of equipment and environment rather than in terms of separate objects.

This tendency of Soviet industrial designers manifested in a $1970 \mathrm{col}-$ lection of reports on VNIITE research relating to domestic objects, characteristically titled 'Artistic Engineering of Everyday Equipment'. In the opening article, designers Aleksandr Riabushin and Elena Shemshurina, together with VNIITE director Iurii Soloviev, described a modern home as 'a complex system, resulting from the labour of different specialists - architects, artists[-engineers], media and communication workers, mechanical engineers, workers of light and woodworking industries, and so on'. ${ }^{8}$ Design was not only recognised as a complex activity instead of a modernised applied art, but the product of design appeared more complex than just the object itself. While neodecorativists complicated their handmade singular or small-edition objects by embedding them in a web of symbolic meanings, VNIITE designers increasingly saw objects as being elements of 'equipment' and 'furnishings'.

This new vision relied on both the legacy of productivism and the contemporary western European shift towards metadesign (the approach to each industrially produced object as 'a part of the same combinatorial, commutative milieu'). ${ }^{9}$ Soviet designers reconceptualised consumer objects as tools, or props, of everyday activities. As Tom Cubbin demonstrated in his article on the Soviet design of domestic equipment, ${ }^{10}$ this conceptual move was inspired by the writings of the philosopher Karl Kantor, head of the laboratory of technical aesthetics at VNIITE. Kantor drew inspiration from a particular line of productivist thinking of the 1920s that anticipated the disappearance of singular objects and their replacement by different 
kinds of integral equipment: 'material installations' (the concept of Boris Kushner) ${ }^{11}$ or 'unembodied energy' (as noted by Nikolai Tarabukin). ${ }^{12}$ Discussing Kushner's concept of 'material installation', Kantor believed in the 'death of an object' in the communist future, when commodity relations would disappear altogether and people would have the possibility of satisfying their needs without using objects. Material installation, for Kantor, is a dynamic system that takes diverse forms and satisfies continuously changing needs. Kantor viewed the projects for collapsible furniture, developed by Soviet designers in the 1960s, as a step towards such 'material installations' ${ }^{13}$ However, the final goal of Soviet designers should be the overcoming of objects - razveshchestvlennie, which Cubbin aptly translated as 'de-artefactualisation'.$^{14}$ Shifting from objects to 'material installations' would eventually lead to 'total' design that left no room for irrational consumer desires and the fetishisation of objects. While this idea, shared by Kantor and his colleagues Riabushin, Rozenblium, the architect Viacheslav Loktev and others, seems to align with the planned economy and ideological dictates of the Party, it also incorporated elements of diversity and play due to the dynamic character of this future, de-artefactualised material culture, reminiscent of the then popular western New Left critique of design and urban planning. ${ }^{15}$

However, while VNIITE developed clever predictions regarding the future of de-artefactualisation, millions of Soviet people still needed chairs and plates, refrigerators and vacuum cleaners, radios and TV sets to ensure that their everyday lives were modern and satisfying. What practical measures could designers take to meet the needs of Soviet people whose consumer choices were growing increasingly discerning and who were hardly dreaming of a de-artefactualised brave new world? ${ }^{16}$ This chapter scrutinises concrete projects for the modern Soviet home, developed at VNIITE throughout the 1970s-early 1980s. It examines the different methods that designers used to overcome the narrow focus on a singular object in order to progress towards 'total design'.

\section{Ideal objects}

In the 1960s VNIITE was preoccupied with developing evaluation criteria and methodologies for design processes. Household objects were the first item on the agenda: from 1965 to 1966, in cooperation with the Design Institute of Poland, VNIITE conducted research on the contemporary standards of domestic space and furnishing for different consumer groups, and on consumer requirements for different categories of goods. This research was related to the development of typologies for household objects in new, prefabricated flats that I discussed in Chapter 2. Altogether, these activities were aimed at preparing a solid ground for work under contracts with industries. In 1970 VNIITE published a final 
report containing detailed descriptions of typologies (nomenklatura) for different functional zones (kitchen, bathroom, etc.) and types of equipment (for example, storage units, radio equipment). ${ }^{17}$ The report suggested that by the start of the next decade, VNIITE would finalise an optimal typology for all domestic goods, thus achieving a perfect order of things. The designers could now concentrate on prototypes for concrete household objects - the domain of VNIITE Department No. 8, 'consumer product design' ${ }^{18}$ Three consumer objects, designed by this department at three different points in the 1970s, illustrate the evolving ideal of an object for educated and discerning Soviet consumers.

\section{Vitiaz' alarm clock, 1972}

One of the first practical designs emerged from Department No. 8 in 1972: a new alarm clock model. According to the classification of household goods in Soviet trade, all types of clocks belonged to the category of kul'ttovary ('cultural goods'), together with radios, photo and movie cameras, stationery and toys. ${ }^{19}$ The twin practical and symbolic functions of a clock in modern urban society had been clear to Bolshevik leaders from the start of their power and was instrumentalised by the 1920s movement for the scientific organisation of labour. ${ }^{20}$ One prominent participant in this movement, journalist and critic Platon Kerzhentsev, was concerned with the lack of efficiency at work and in daily life. He described time as a commodity that foreigners learned to revere, but that Russians kept disregarding and misusing. The League of Time that he established in 1923 not only engaged in fighting lateness, needless meetings and excessive speeches, but also in the rationalisation of working, public and domestic space in order to reduce unnecessary movement. ${ }^{21}$ Some League of Time members wore oversized watches as their emblem; Richard Stites comments that it was a poignant choice in a country where less than a million watches and clocks were produced in 1928. Watches as a symbol of modernity emerged in a famous 1923 poster by Rodchenko and Mayakovsky, advertising the production of a Russian-Swiss firm Moser. The poster displays a human figure combined from different-sized timepieces and declares that 'A person must have a watch' ${ }^{22}$

Beginning in the 1930s, when all Soviet clock workshops were consolidated into several big factories and ultimately united in a trust, timekeeping devices primarily served the needs of the railways and the Red Army; needs that became even more pressing during the Second World War. After the war, Soviet factories gradually established the mass production of watches and clocks for ordinary consumers rather than just for highranking military men. In 1965 the USSR produced 30 million high-quality wristwatches. ${ }^{23}$ A 1967 textbook for vocational schools claimed that the USSR was second in the world after Switzerland in the production of 
complex and high-quality timepieces, 'leaving West Germany, Japan, the US and England behind'. ${ }^{24}$ By the early 1970s the USSR had achieved the production of over 40 million timepieces of 80 engineering types and 1,800 modifications of external form per year. ${ }^{25}$

The aesthetic turn, emerging in the mid-1950s, immediately affected the watch industry. Timepieces entered the category of 'decorativeapplied art'. In 1954 the Research Institute of the Time Measurement Industry (NIICHASPROM) asked the administration of the Mukhina School to include the design of clocks and watches in the topics for diploma projects in the departments of carpentry, glassmaking, metalwork and ceramics; projects that would later be used to develop new brands. ${ }^{26}$ The aesthetic turn revived the 1920 s campaign to rationalise everyday life, including time measurement. Watches and clocks became essential elements of modern Soviet flats as imagined by planners, engineers and designers. The newly established design services at watch and clock factories presented 'honest objects' of strict, expressively functional form and minimal decoration. Table clocks from the early and mid-1960s typically imitated home electronics that, in turn, resembled modular furniture, while wall clocks from this period often had plastic cases with sharp, asymmetrical, geometric shapes and simple combinations of colours (mostly black and white). Apparently, modern Soviet clocks would suit one of two home arrangement principles, highlighted by the critic Piletskii in 1964. They would either integrate into a rhythmical structure of home furnishing or present a striking contrast to it. ${ }^{27}$ Both principles, however, negated the predominantly decorative meaning of the clock in the home, characteristic of the late Stalin era. The designer and collector of Soviet objects Azat Romanov explains this negation through two items from his impressive collection of Soviet objects: the table clock Vesna, produced in 1963 by the Vladimir clock factory (plate 7); and the wall clock Iantar' from the same year, a product of the Orel clock factory (plate 8).

The case of the table clock Vesna in the shape of an irregular trapezium looks as if it is declaring that the philistine attitude towards clocks as lavish decoration for furniture has ended and a new time has arrived. The triangle of the wall clock Iantar' by the Orel clock factory markedly differs from old-time wooden cases; it is devoid of 'excessive' details like continuous numbering on the clock face. Twelve wire stripes and three digits are now enough to tell the time: nothing extraneous! ${ }^{28}$

Both items would ideally fit a living room, study or bedroom in a new prefabricated flat. The asymmetry of Vesna could rhyme with the irregular trapezoid shape of the radio-receiver Moskvich, also issued in 1963 by the Moscow Aerophone factory (plate 9). The triangular black case of Iantar' would be balanced by an object of applied art: for example, by a minimalist black porcelain vase produced in the early 1960s at Leningrad Porcelain 
Factory after the design of Anna Leporskaia, a 'veteran' of the avant-garde (plate 10).

For Riabushin and his colleagues at Department No. 8 in VNIITE, dedicated to 'ordering the everyday environment in general', ${ }^{29}$ designing clocks was an opportunity to express a rationalised daily routine. After being commissioned to design a new model of alarm clock for the Rostov clock factory, Department No. 8 chose simplification of use as the guiding design principle. ${ }^{30}$ The Rostov clock factory, founded in 1955 in Rostov-onDon in south-eastern Russia, specialised in the alarm clock brand Vitiaz'. Its 1972 contract with VNIITE required that the design correspond to the factory's materials and technology and the guaranteed patent clearance in the US, Switzerland, Japan and Yugoslavia. The design team, including the heads of Department No. 8 Boris Neshumov, Riabushin and A. Kholodkov, assisted by engineer A. Sergeev, proposed two variations of the alarm clock's external design:

A a brightly coloured case of spherical shape rotatable around a vertical axis;

B a white case of horseshoe shape.

Both models could be produced from polystyrene by an injection moulding machine or stamped from a sheet of steel and then painted; the clock face's covering and hands would be polystyrene (transparent and black/ white, respectively) with winding knobs of chromium-plated steel.

In both designs, the influence of Swiss designer Max Bill, the rector of the Ulm Institute of Design, is evident. He was a proponent of the 'good form' concept, a science-based, socially responsible design that informed much of the development of Soviet technical aesthetics. Bill designed a series of white table and kitchen clocks for the West German manufacturer Junghans, which became classics of mid-century design. ${ }^{31}$ However, the new Vitiaz' variants were developed not only as an adaptation of the famous Swiss designs, but also as a response to the flaws of their Soviet predecessors. Both A and B models showcased how the level of detail had been reduced to enable more immediate comprehension, crucial for a person who has only just woken up. The designs required the replacement of an alarm hand with a dial in the form of an orbit around the clock face. In model A, the alarm dial is recessed in relation to the face, while in model $\mathrm{B}$ the dial and the face are separated by a chromium-plated metal ring. The design team believed that this solution precluded the previous confusion that often occurred between hour and alarm hands: 'One mainly uses an alarm clock as a regular clock, and one uses the alarm hand only when setting the alarm. When the alarm rings, this hand is obscured by the hour hand. In the new models, we stress the main function of the clock face: indication of time. ${ }^{32}$ Therefore, rather than stressing the disciplinary 


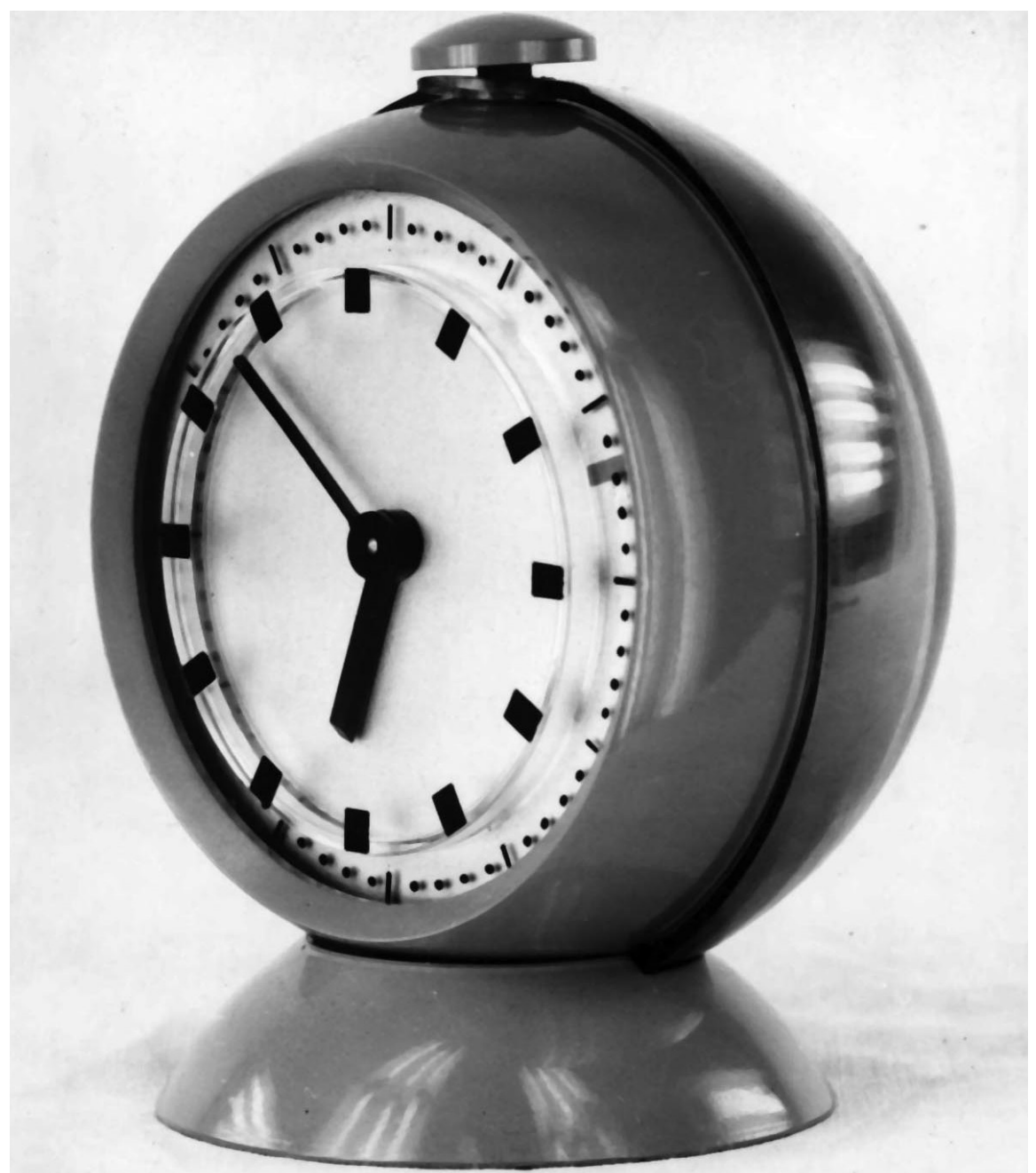

All rights reserved and permission to use the figure must be obtained from the copyright holder.

4.1 A. Kholodkov et al., model of alarm clock Vitiaz' for Rostov clock factory, variant A, 1972.

function of an alarm clock - waking a user up for a working day and thus facilitating work discipline in the spirit of the 1920s League of Time - the VNIITE team minimised this function visually and spatially. Alternatively, one can see this design as increasing the functional capacity of an object, precluding its periodical function (a morning alarm) from limiting its usefulness as an instant time-measurement device.

The new Vitiaz' also promised functional convenience: its handles for time and alarm setting were knurled knobs, while the winding knobs were trapezoid. Instead of pictograms, typical of the control panels of Soviet clocks, this model had typographic labels. This was due to a recent 


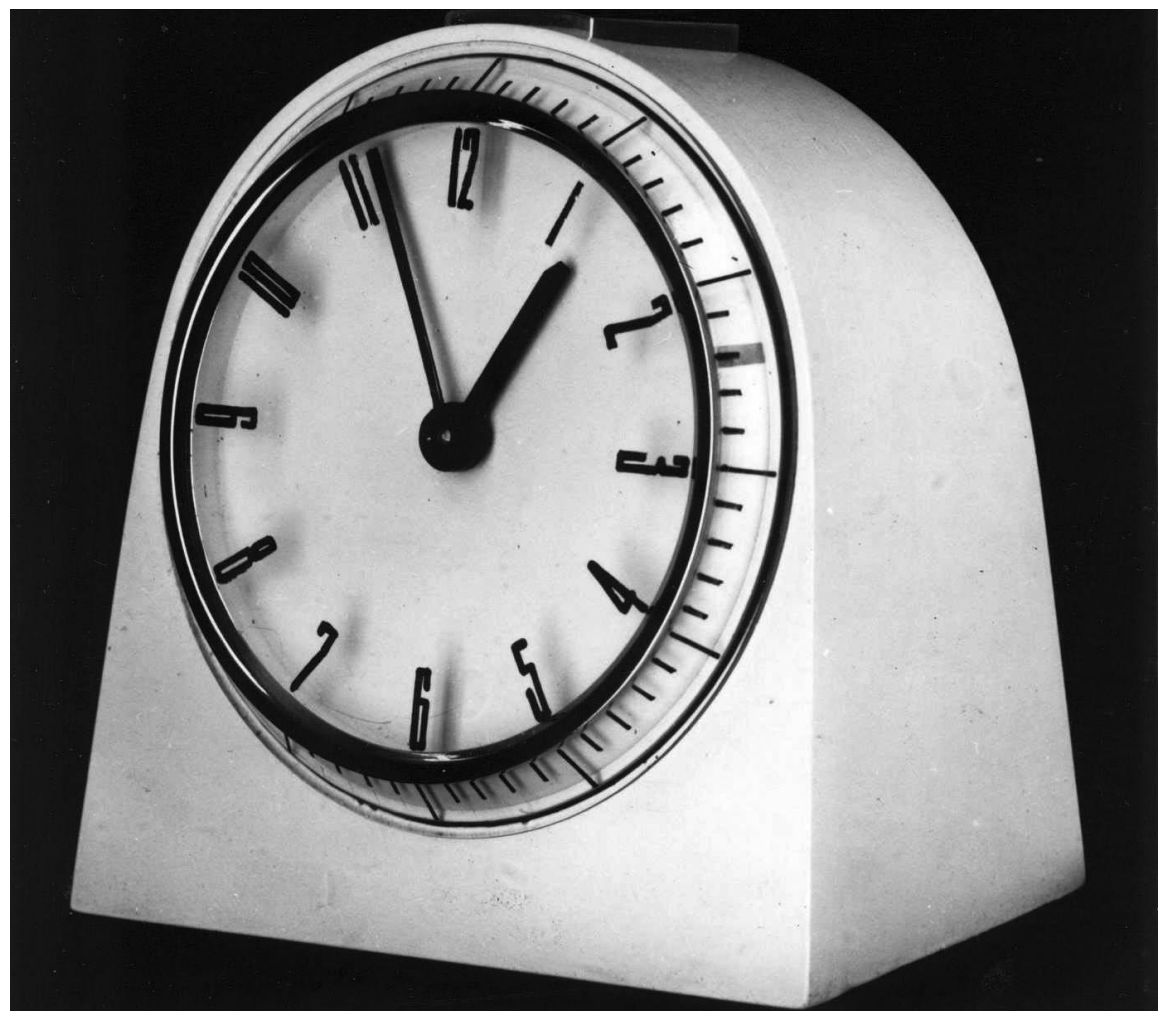

All rights reserved and permission to use the figure must be obtained from the copyright holder.

4.2 A. Kholodkov et al., model of alarm clock Vitiaz' for Rostov clock factory, variant B, 1972.

consumer poll that showed the frequent difficulties users encountered in comprehending pictogram indicators on clocks' control panels, even after prolonged use. In model A, the control panel was protected by a dome of transparent polystyrene, whereas the horseshoe shape of the model B clock guaranteed steadiness. This aspect was crucial in the event of the user switching off the alarm while half asleep, which is often done in the dark by touch. As such, the 1972 Vitiaz' appeared user-friendly both in terms of comprehensibility and handiness, demonstrating the important role of ergonomics in VNIITE's theoretical and practical activity. ${ }^{33}$ Userfriendliness was the ideal object-person relationship, which, according to the VNIITE system of quality evaluation from 1967, constituted a key part of the operational aspect of quality. ${ }^{34}$ The system notably included an object-environment relationship as another component of the operational criterion. The alarm clock designers also considered this problem, at least in model A: the bright colour of the case distinguishes the clock in the interior as a mobile object, not fixed to a permanent place. As for the aesthetic aspect of quality, the designers treated the shape and physical 


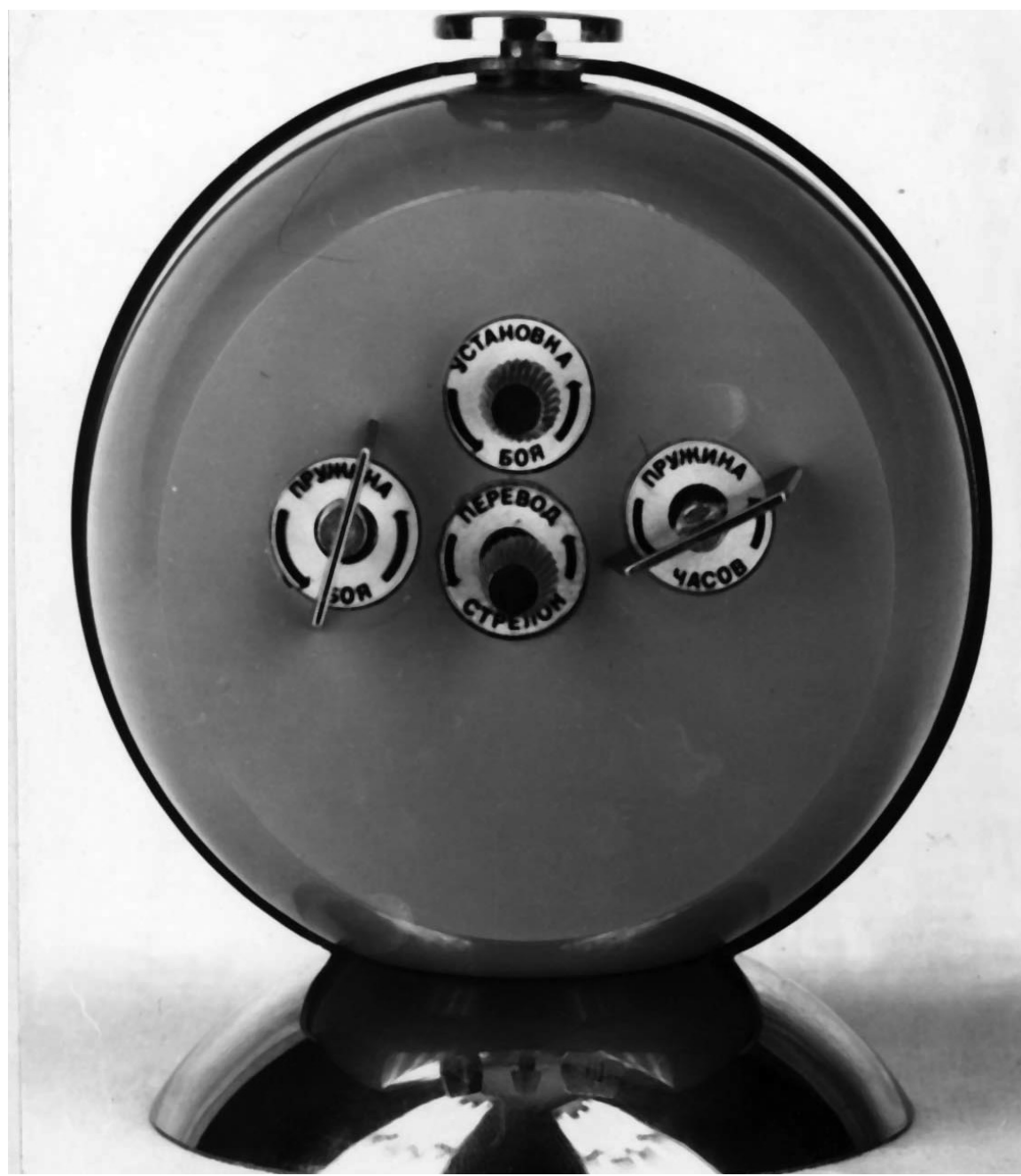

All rights reserved and permission to use the figure must be obtained from the copyright holder.

4.3 A. Kholodkov et al., model of alarm clock Vitiaz' for Rostov clock factory, variant A, control panel, 1972.

qualities of the material as signifiers of an object's vulnerable position visà-vis the user: 'the round case of model A with a transparent dome over the control panel metaphorically expresses the character of the clock as a fragile and subtle mechanism.' ${ }^{35}$ This appearance, the designers believed, would encourage users to handle the clock carefully. For model B, in contrast, the stable horseshoe shape made the object seem durable and steady even to not-quite-conscious users who had not fully awoken. Thus, by the means of design, Department No. 8 offered two modes of objectuser interaction. In both cases, the designers downplayed the signification 
of an alarm clock as a disciplining tool. Instead, a new Vitiaz' would enter a Soviet home either as a subtle reminder, through its materiality, of the fragility and thus high value of time, or as a reliable guardian of daily routine. A reading of Bill's 1956-57 kitchen clock by MoMA curator Pamela Popeson explains the aspiration of the 1972 Vitiaz' designers:

it is in charge, you just know it is. You can feel it, and not because it throws its weight around-no, not at all. It doesn't have to. It hangs up there, in its splendour, in its quiet understated elegance, ticking away, steady and sure, keeping and marking time, an ideal example of perfect form and moral purpose though design. ${ }^{36}$

\section{OKA-USh refrigerator, 1973-74}

Since the unfolding of the aesthetic turn, its proponents have viewed the refrigerator as an exemplary modern object. "Along with the excellent refrigerators and TV sets of modern forms that can beautify any flat, [our industryl forces horrible nickel-plated beds with decorative knobs and styleless ottomans into our daily life', complained the art critic Virko Blek in a 1957 article. ${ }^{37}$ In the same year, Novye Tovary (New Goods), the bulletin of the All-Union Permanent Pavilion of the best models of consumer goods, ${ }^{38}$ introduced two new models of domestic refrigerators, including Oka, produced by the Murom machine-building factory (the brand name comes from the river by which the city is located). The article argued that this new compressor-type refrigerator 'attracts us first of all by its beautiful internal and external finishing' and listed its conveniences, such as a capacity of 125 litres, numerous shelves (including door shelves, 'decorated with stripes of anodised aluminium') and a separate freezer of 18.5 litres. The illustration to this entry shows a housewife amazed at the view of a new fridge, proudly opened by her husband. ${ }^{39}$

Refrigerators attracted much attention from economists and art critics alike due to the centrality of the kitchen as a mid-century site of scientific modernisation. ${ }^{40}$ Soviet officials' interest in modern kitchen and domestic appliances began in the mid-1950s and culminated in the famous display of the all-electric GE kitchen at the American National Exhibition in Moscow in 1959; the kitchen included a refrigerator-freezer. ${ }^{41}$ Aiming to 'catch up and overtake' the US in the production of home appliances, the USSR exponentially increased the production of refrigerators over a decade: it produced approximately 529,000 in 1960 compared to a mere 1,200 in 1950, 49,200 in 1953 and 151,000 in 1955. ${ }^{42}$ By 1964 this number had increased to roughly 1.7 million, and by the end of the eighth Five-Year Plan (1966-70), 4.17 million refrigerators had been produced ${ }^{43}$ (though less than the planned number $-5.3-5.6$ million). ${ }^{44}$ Citing the data of VNIIKS (Research Institute for Consumer Opinion), Natalia Chernyshova notes the growing availability of the appliance: 'A humble 17 percent could 
keep their food fresh in a refrigerator in 1965, but in the early 1980s some families could even boast of having two fridges. ${ }^{45}$ Chernyshova warns the reader against taking these numbers as an indication of a great Soviet lag behind the West, as American-sponsored mass consumption was a novelty in Western Europe and post-war statistics on electrical appliance ownership in the countries under the Marshall Plan were not very high either. ${ }^{46}$ Refrigerators did not become indispensable in Western European kitchens until the 1960s. Even in the US, a fridge only became a home necessity rather than a luxury in 1960, as Helen Peavitt demonstrates in her recent study. ${ }^{47}$

As was typical for the Soviet consumer goods industry, the problem with refrigerator production was not so much quantity as quality. As the employees of VNIITE's department of social-economic research explained in 1965, the initial saturation of the domestic market by the increased production of household appliances, when the market 'absorbed the entire output', stimulated further production of the same models while obscuring the need for diversity. This dynamic eventually led to the production of specific models beyond demand: consumers observed many similar, low-quality goods of different brands produced by multiple factories (in the case of refrigerators, thirty-four brands were produced by twenty-six factories in 1965), but could not obtain models suitable for their specific purposes. This lack of optimal varieties of consumer goods was VNIITE's central concern from the start, as discussed in Chapter 2. In the case of refrigerators, it meant the predominance of free-standing tall refrigerators ('cabinet refrigerators', in Soviet terminology) at the expense of various mini- (wall-hung, table-top and table-height) and built-in fridges. Soviet factories only produced a few models of table-height fridges. A wall-hung fridge was issued solely by the Council of People's Economy in Riga, and even that was too bulky for prefab kitchens; table-top and built-in fridges were completely absent from production. The responses to the VNIITE consumer opinion poll, published in June 1965 in the newspaper Nedelia (Weekly), showed the significant demand for precisely those fridge types that the industry kept ignoring. The change in demographic trends and lifestyles increased the demand for refrigerator types that differed from the 'cabinet': for example, the decrease in the average family size, coupled with the growing public enthusiasm for hiking and automobile tourism, raised the demand for compact table-top refrigerators. While the demand for high-capacity refrigerators grew in the US and Western Europe, such models were unsuitable for the small kitchens of Soviet prefabricated flats. They also did not correspond to the modular structure that was established in the Soviet furniture industry. In addition, Soviet refrigerators had a greater weight per volume and mostly lacked temperature regulators, door-opening pedals, auto-defrost and moveable shelves. Moreover, they often had technical deficiencies. 
However, as the VNIITE researchers bitterly admitted, Soviet consumers were forgiving: they simply had no choice but to buy imperfect models. Furthermore, they were barely familiar with the Western diversity of refrigerator types and thus had no opportunity to make a comparison. Lacking alternatives, individuals were happy to purchase inconvenient and oversized fridges. ${ }^{48}$

After half a decade of discussing these problems, the industry began to take steps towards improving the diversity of household appliances. For example, the Leningrad branch of VNIITE (LF VNIITE) designed a fridge bar for the Leningrad Association of Mechanical Engineering and Production of Electronic Devices (Lenmashelektropribor) in 1972. The artistic-technical council of LF VNIITE, which included VNIITE designers and representatives of the client, noted the high quality of the model but suggested reducing its height, including additional shelves and strengthening the stylistic unity of the external form. The initial plan for internal neon lighting had to be abandoned in favour of an incandescent lamp because of the lack of necessary equipment in production. ${ }^{49}$

A year later, Department No. 8 at the central VNIITE worked on two models of the Oka-USh electric refrigerator brand on commission from the Ordzhonikidze Machine Engineering factory in Murom. ${ }^{50}$ This factory initially produced military and industrial equipment but began the production of household appliances after the Second World War. (Producing domestic goods in armaments and car factories was a common practice in the USSR, but not a uniquely Soviet one. For example, General Motors owned the famous American refrigerator-producing company Frigidaire from 1919 to 1979.) $)^{51}$ In 1974 the designers Valerii Iabrov and Vladimir Rezvin presented the two models as part of a universal system of refrigerator types that could satisfy diverse needs. The system would be based on the combination of different-size compartments, composed of panels filled with polyurethane foam. Both models were full-height and two-compartment, accommodating 275 and 350 litres respectively. In both models, the upper compartment could work both as a freezer and a regular refrigerating unit, whereas the lower, larger compartment operated at temperatures above $0{ }^{\circ} \mathrm{C}$ and was meant only for short-term storage. The lower compartment included airtight containers for foodstuffs requiring low humidity, such as fruit, vegetables and unpackaged products, and a humidity accumulator to absorb excessive moisture. The control panel was located at the end of the fridge's top panel, above the upper compartment's door, supposedly at eye-level with the tallest family member. It included a temperature switch and thawing indicator that would signal a malfunction.

For further user-friendliness, the designers offered vertical division of both compartments into two zones: to the left, a wider zone with cantilevered moveable trays and shelves, nine altogether, and to the right, 
a narrower zone with cantilever shelves for storing three-litre jars with homemade preserves and jams from the produce of ex-urban vegetable plots or countryside households, sent by relatives from the country. Such a division reflects the typical Soviet habit of using homemade preserves to compensate for food shortages (still prevalent in the 1970 s beyond big urban centres). In addition, many people preferred homemade pickles or jams to those available in stores. However, as the VNIITE report observed, preserves were rarely used, mostly being consumed at special family dinners, and therefore it was logical to spatially separate them from the daily used foodstuffs. The shelves in the two zones differed in height, producing a staircase structure: the idea was presumably to avoid the impression of overcrowding and to smartly distribute the weight of the contents. Additionally, the door shelves would store cheese and butter.

In designing the external form of their refrigerator, Iabrov and Rezvin did not follow the vision of an immaculately white refrigerator as a symbol of perfect domestic hygiene, as popularised by Raymond Loewy in the 1930s. ${ }^{52}$ Instead, they drew upon two recent Western trends. The first, the colour-coordinated kitchen of the 1960s, was used for a 275-litre fridge model. The second trend, the imitation of wooden furniture in kitchen equipment that was gaining prominence in the 1970s, informed the design of a 350-litre refrigerator. In the first instance, Soviet designers followed the example of the American and Western European refrigerator manufacturers who created ranges of 'fashionable colours' thanks to enamel paints by Du Pont. The VNIITE design report included a table of colours for the fridge's smooth side walls and doors. These, together with sculptured door handles, were supposed to produce a modern expressive object that would proudly replace the monotonous and clumsy Soviet fridges. In the second instance, the report carefully admitted that the model's outer appearance 'somewhat differs from a traditional, commonly accepted vision of a fridge', because its door was finished with a synthetic skin imitating the texture of wood, while its long horizontal metal handles and side walls were coated with leather-imitating synthetics. ${ }^{53}$

If the smaller Oka-USh model demonstrated a belated catching-up with Western product design in the 1960s, the larger model proudly displayed how cutting-edge Soviet kitchen technology was. In form and style, the larger model shared clear connections with American refrigerators of the same period. Peavitt summarises how opulent American fridge advertisements of the 1970s and 1980s were: "you could buy a "sapele wood" finish Tricity or a "Copperline" Electrolux, whose "gleaming 'copper-tone' exteriors and shining trims" were "beautifully appointed" to complete the dream kitchen' ${ }^{54}$ The VNIITE report speaks of the same new, international trend: 'Recently the design of household appliances and interiors of kitchens and bathrooms has approached the decisive turn from pronouncedly 


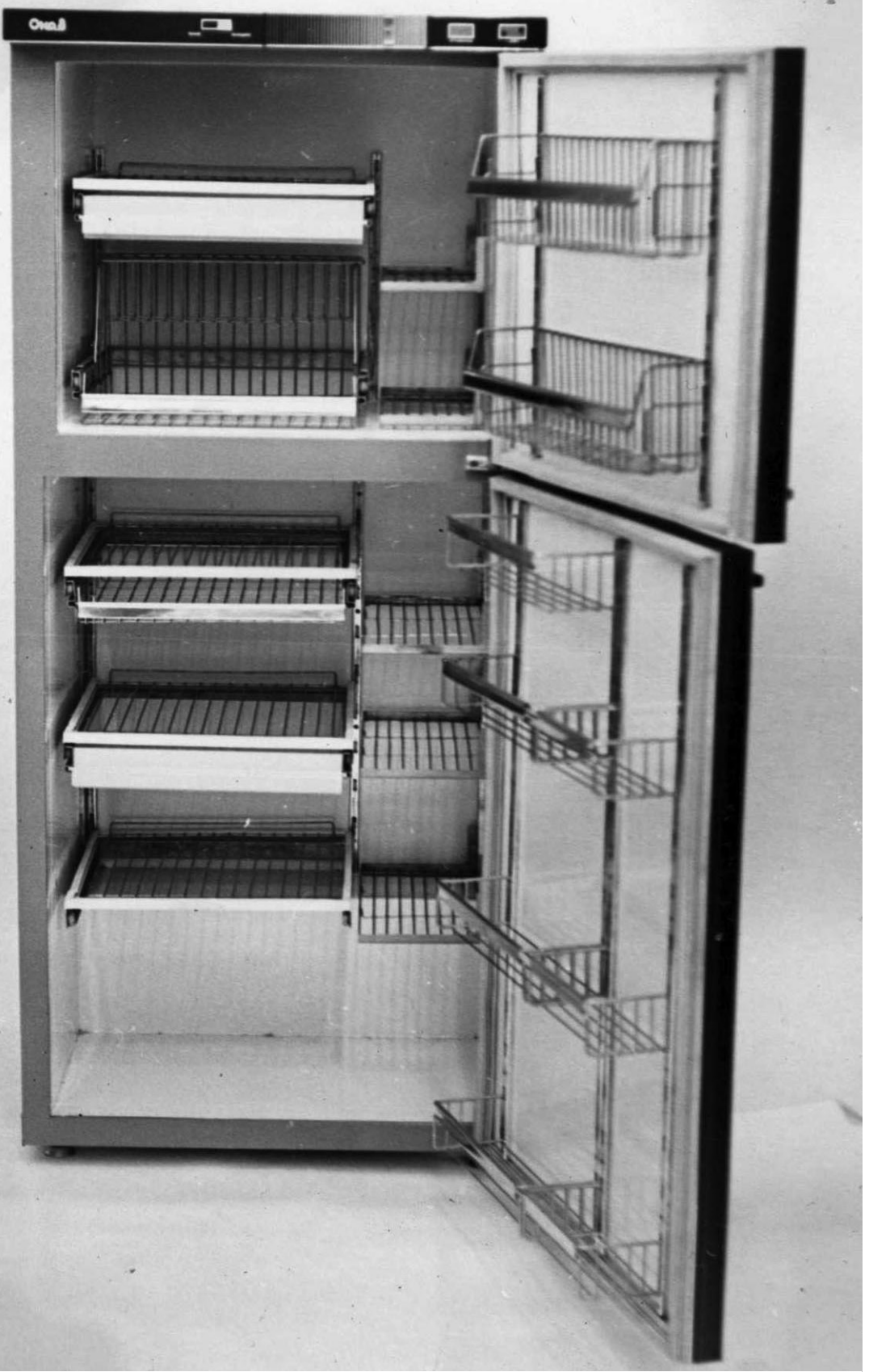

All rights reserved and permission to use the figure must be obtained from the copyright holder.

4.4 Vladimir Rezvin et al., model of the refrigerator OKA-USh with a capacity of 275 litres, interior view, 1974. 


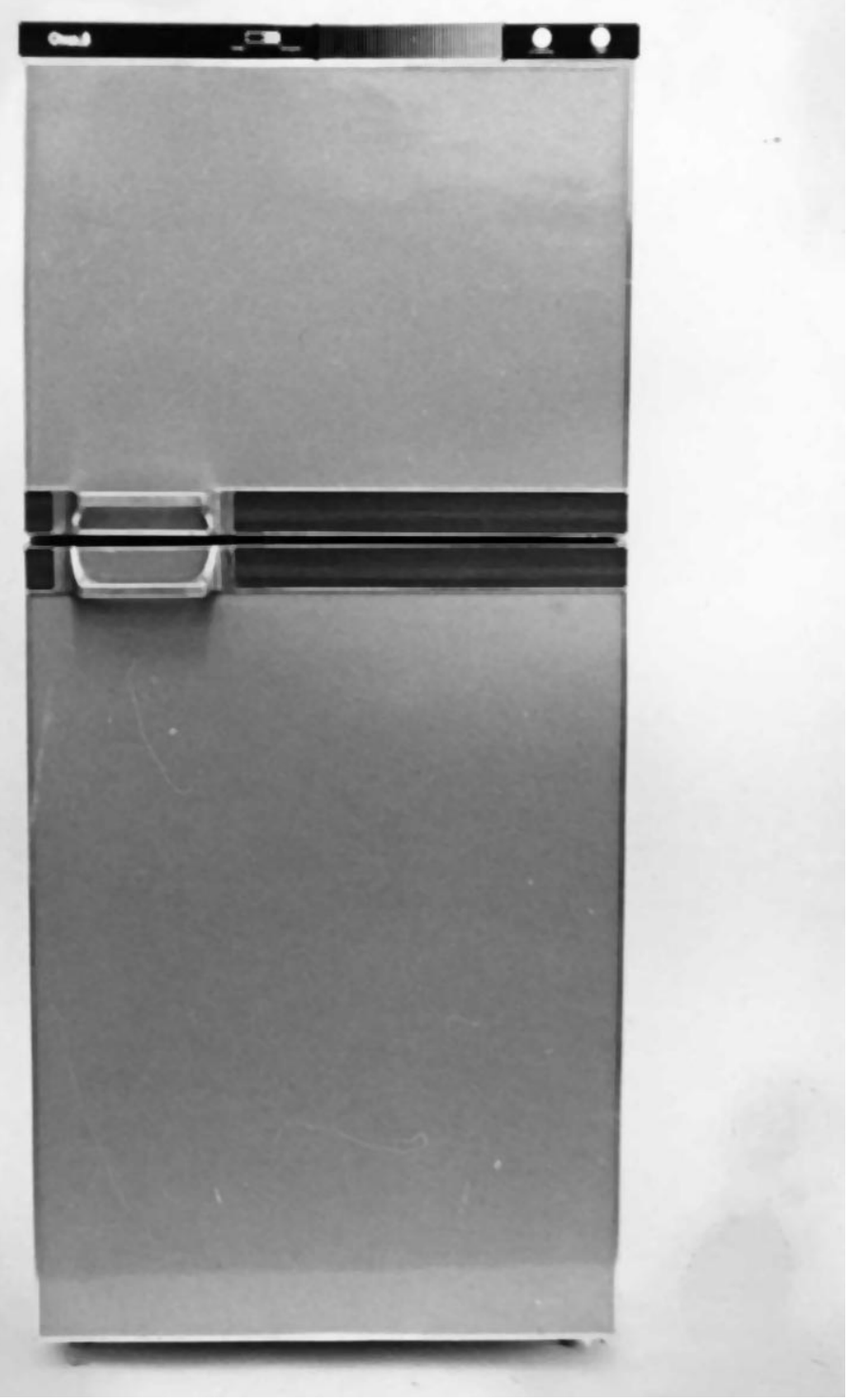

All rights reserved and permission to use the figure must be obtained from the copyright holder.

4.5 Vladimir Rezvin et al., model of the refrigerator OKA-USh with a capacity of 275 litres, general view, 1974.

rational, strict and technological solutions to softer, more humane ones. This has led to a widespread use (or imitation) of natural materials such as wood, leather, copper, etc. ${ }^{55}$ Ten years previously, such imitation would have been an example of kitsch for the advocates of the aesthetic turn 


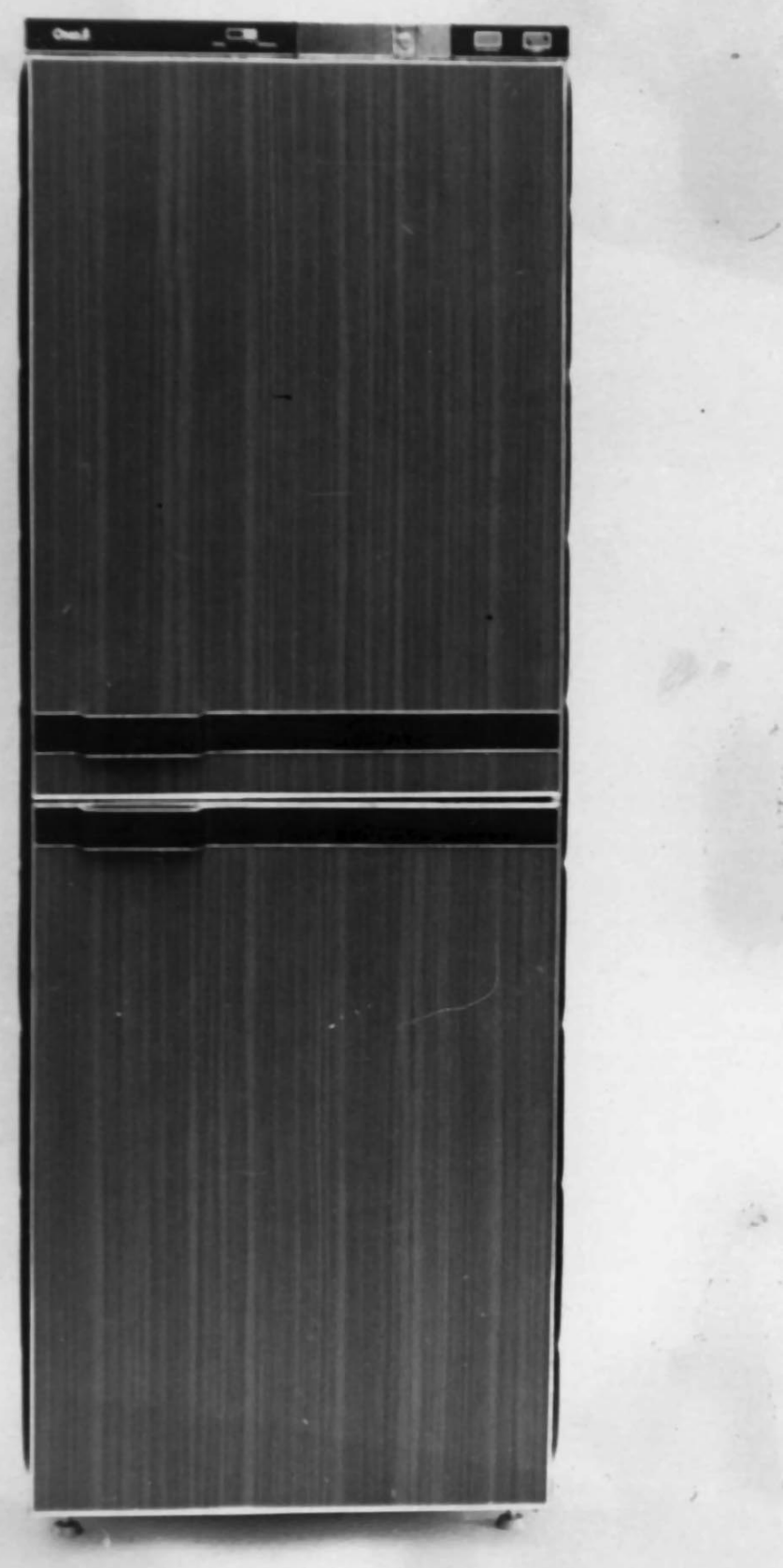

All rights reserved and permission to use the figure must be obtained from the copyright holder.

4.6 Vladimir Rezvin et al., model of the refrigerator OKA-USh with a capacity of 350 litres, general view, 1974. 
(recall Piletskii's 1964 article criticising electronic appliances that imitated furniture). ${ }^{56}$ Soviet designers now explicitly presented the new Oka fridge as free-standing rather than built-in and 'similar to furniture in its character' ${ }^{57}$ However, if a fridge imitating an expensive cupboard would offend a Soviet modernist as a deceitful object in 1964, it appeared to be 'humane' by the 1970s - in tune not only with Western design trends, but also with the discussion of 'spiritual utility' provoked by neodecorativism in the decorative arts that was spreading to the larger community of art and design professionals.

The interior of the new Oka fridge, however, would surprise the firsttime user with bright yellow and orange panels: 'such a contrasting combination of external and internal volumes produce a certain surprise effect'. The interplay between the cosy familiarity of a cupboard-like appearance and the striking brightness of its internal walls was meant to introduce diversity into the Soviet order of things. The two-version design of the OkaUSh granted consumers a choice between declining modernist aesthetics and the emergent postmodernist aesthetics, while also complicating the notion of domestic hygiene, presenting it as irreducible to the immaculate shiny surfaces. The VNIITE team strove therefore to not just catch up with Western design, but to immediately leap forward while broadening the space for diverse consumer preferences.

\section{Buran vacuum cleaner, 1977}

Even more than the brilliantly white refrigerator, the vacuum cleaner was an outspoken symbol of domestic hygiene in the mid-twentieth century. Moreover, with the post-war growth of consumer culture in the EuroAtlantic world, it came to embody the materialist fantasies of the middle class, but also gender and class hierarchies, as epitomised in Richard Hamilton's famous collage Just what is it that makes today's homes so different, so appealing? (1956). Among the 'pop' household objects depicted in this artwork is a vacuum cleaner with a streamlined, rounded shape and an impressively long cable extending across the staircase ('ordinary cleaners reach only this far', says the tag on the middle stair level). This wonder of household technology defines the role and status of the (female) housekeeper, who looks, indeed, merely like the vacuum's appendage far behind the scene of the middle-class couple's obsessive and erotic personal care procedure.

Around the same time, in the late 1950s, the Soviet vacuum cleaner appeared as the rescuer of Soviet women from the burden of domestic chores that persisted forty years after the Bolsheviks' denunciation of women's ties to housework. The proponents of the aesthetic turn often referred to Lenin's 1913 anticipation that "electric lighting and heating of every home will relieve millions of "domestic slaves" of the need to 
spend three-fourths of their lives in smelly kitchens'. ${ }^{58}$ Together with kitchen appliances and washing machines, a vacuum cleaner would not just ease the notorious double burden problem - the pressure to combine money-earning work with unpaid domestic labour - but also give women the time for hobbies and self-education. The introductory section of the 1965 VNIITE questionnaire about consumer preferences sadly admitted that housework occupied women's free time, leaving them with 'so many unread books, unseen theatre plays, and missed outings'. ${ }^{59}$ Indeed, a Soviet woman remained not only a 'kitchen slave' to her family in 1965 - to use a popular 1920s expression - but also a slave of domestic dirt and dust. The growth in the national production of vacuum cleaners was more than twice as slow as that of refrigerators: starting at 45,500 in 1953 (compared to 49,200 refrigerators), the number of Soviet vacuum cleaners reached only 830,000 by 1965 (compared to 1,875,000 fridges). ${ }^{60}$ Furthermore, this modest amount was made up of just two types: floor cleaners and hand-held upholstery cleaners. Upright cleaners, widespread in Western countries and favoured by VNIITE as the most suitable for a modern home, were completely ignored by Soviet industry ${ }^{61}$ Bulky, noisy, inefficient, lacking a typology for spare parts and a sufficient diversity of nozzles - in short, not user-friendly - Soviet vacuum cleaners perfectly illustrated the disorder of things in what was supposed to be a rational socialist consumer culture. The internal VNIITE report did not hesitate to highlight their poor design compared to Western models. For example, the Oreol cleaner, produced by the mid-1960s in the home electronics factory of the Leningrad Council of People's Economy, was considered a conglomerate of parts not just because it was visually discordant due to the different materials used, but also because it demanded different technical operations, burdening and confusing a prospective user. Moreover, it did not fit into a clear category: its weight (3.85 kg with nozzles) disqualified it as an upright, while a short hose made it a poor floor cleaner. In comparison, a light, low-noise Rapid by Siemens impressed the VNIITE designers due to its compact and visually harmonious canister made of shockproof thermoplastic and its ease of assembly. ${ }^{62}$

The 1960s fashion for Space Age forms received no better commendation than at VNIITE. From 1957, the Dnepropetrovsk Aggregate Plant (Ukraine) produced two similar vacuum cleaner models with elongated, streamlined shapes. ${ }^{63}$ Both were the products of reverse engineering, widespread in Soviet factories' engineering bureaus. Raketa was based on a 1930s model by the famous Swedish manufacturer Electrolux, while Chaika closely copied a design by the Dutch firm Erres. ${ }^{64}$ When modifying the Western models, the factory designers attempted to strengthen the Space Age allusions by further elongating the shapes of the cleaners and making them more 'dynamic'. The vacuum cleaner Saturn/Saturnas (with Russian and Latvian name variants), designed since 1962 at the Welding 
Equipment Plant in Latvia, was a reverse-engineered 1955 Constellation model by the famous US brand Hoover. ${ }^{65}$ Alluding to the recent triumph of the Soviet Union in space (Iurii Gagarin's flight took place on 12 April 1961), the designers made the form illustrate not just a planet but specifically Saturn with its rings. The 1965 VNIITE report dismisses all three models for 'unjustified striving to illustrate the cleaner's name by its appearance'. ${ }^{66}$ Ironically, therefore, Soviet Space Age designs, which are often perceived today as vivid expressions of 1960 s aesthetics, ${ }^{67}$ were interpreted by Soviet designers as irrational and thus deficient. This contradiction neatly demonstrates the complex character of the post-Stalin aesthetic regime of arts that combined a striving for the rationalisation and ordering of things, and the search for a new imagery of socialist modernity.

The 1965 complaint about 'unjustified' vacuum cleaner forms apparently had little effect upon factory-employed designers. In 1968, for example, the Elektromashina ('electronic technology') factory in Prokopievsk (south-western Siberia) presented the Space Age variant of the Buran cleaner, with a shiny, gold canister in the form of two conjoined spheres, evoking images of Sputnik or the planets (plate 11). However, almost a decade later, in 1977, the factory recognised the need for a less imaginative but more user-friendly and original vacuum cleaner. The factory's Research Institute contracted VNIITE to design a No. 7 model of the Buran vacuum cleaner with 'advanced consumer qualities, currently lacking in domestic production'. ${ }^{68}$ The VNIITE team, consisting of designers B. Korolev, E. Shtuden and G. Shmakov and the engineer V. Rozhkova, researched the current state of Soviet cleaner production and recent Western trends. They discovered that even though cleaners were produced in fourteen Soviet factories under six different ministries, this production was still far behind the West in terms of ergonomics, use of progressive materials and external appearance. Upright and portable 'backpack' models were almost nonexistent: instead, low-turn engines that required larger dimensions and weight prevailed. In addition, Soviet industry had not mastered the production of paper and liquid filters, which were considered to be more advanced than those made from textiles at the time. The manufacturers produced only rotary power switches instead of the more convenient, but technically more complex, slider-type switches. This long list of the technical disadvantages of Soviet cleaners included, however, some notes on possible improvement. The Kiev Research Institute of Energy Engineering (VNIIKIEMP) was elaborating a system of standard nozzle sets for domestic vacuum cleaners and planning to finish the work by 1978. Several Soviet manufacturers were also attempting to introduce models that could store the entire nozzle sets inside the canister, following the example of Hoover's C-62KC and Toshiba's VS-70EB and 
SCJ-628, but had not succeeded. ${ }^{69}$ VNIITE stepped in to help realise this plan.

The approach to the new Buran's external shape stemmed from the dismissal of the illustrative principle à la Raketa or Saturnas as irrational and outdated. Working in tune with the currently dominant Western approach to form-giving was essential for the VNIITE team, and their approach was functionalist - or, rather, neo-functionalist, meaning the abandonment of striking forms in favour of strict and elegant ones, usually close to a parallelepiped. Noticing another tendency originating from brands such as Toshiba and Juki in Japan of having more complicated and playful forms, the VNIITE designers nonetheless opted for a parallelepiped integrating different functional units and junctions to reduce the object's visual complexity. ${ }^{70}$ Rather than masking the joint between the lower and upper parts of the canister by a strip of soft plastic, as the factory suggested, the VNIITE designers offered 'a neater solution for the form': moulding a handle (12) together with the upper canister (2) and continuing it as a relief strip around the canister.$^{71}$ This is an example of a structural decoration as favoured by the 1920s constructivists. Five different nozzles were stored in special sockets within a removable cassette on the top of the cleaner (9), while the bottom had clamps for fixing the hose and telescopic wand when the cleaner was stored in a vertical position. The controls - an on/off button and switch for automatic cord rewind (7) and an airflow indicator (8) were on the upper part of the canister and 'plastically processed in accordance with the general stylistic solution, informational clarity and convenience of use'. ${ }^{72}$ The main objective of this design was, obviously, to achieve a harmonious integral form while also making all the different details equally comprehensible. Indeed, the initial Styrofoam model of Buran 7 looks like a sculpture, an aesthetically sound object bigger than the sum of its technical and functional parts. For a stronger effect of integrity, the designers suggested using the same material (ABS plastic) for all the details and a monochrome colour scheme: soft yellow, orange, ochre or salad green for the canister, telescopic wand and hose; beige for the nozzles.

This design was not an original VNIITE solution. As the report admits, it bore a close resemblance to the AEG 1973 model Vampyr Deluxe. Yet Buran 7 differed in a number of ways that VNIITE considered 'significant': the presence of the removable cassette for storing nozzles, the handle flexure for an easier grip, softer angles and unified colouring as opposed to the sharp red-and-white contrast of the Vampyr Deluxe. The latter, ironically, had a clear allusion to avant-garde aesthetics, whereas the VNIITE design demonstrates a softened, 'plastic' functionalism. ${ }^{73}$ Buran 7 was meant to be not so much a productivist comrade and co-worker, but a modest helper, easily integrating into any home.

By the late 1970s such inconspicuous, rounded household objects had 


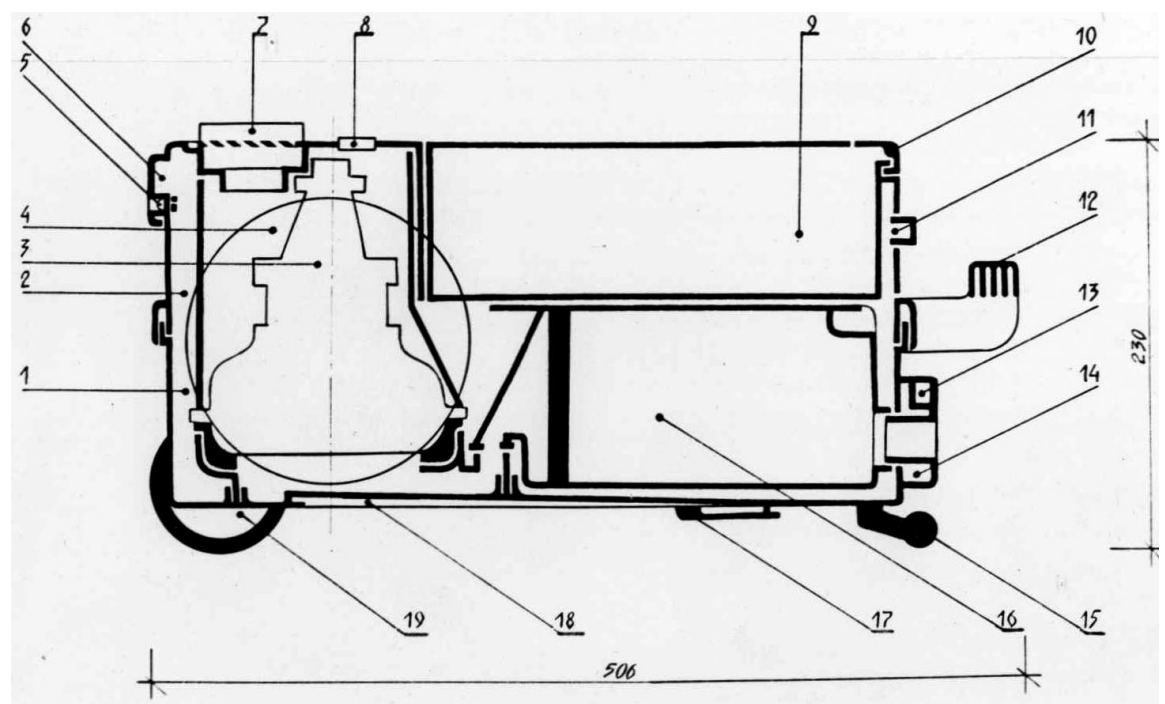

All rights reserved and permission to use the figure must be obtained from the copyright holder.

4.7 B. Korolev et al., layout scheme of vacuum cleaner Buran 7, 1977.

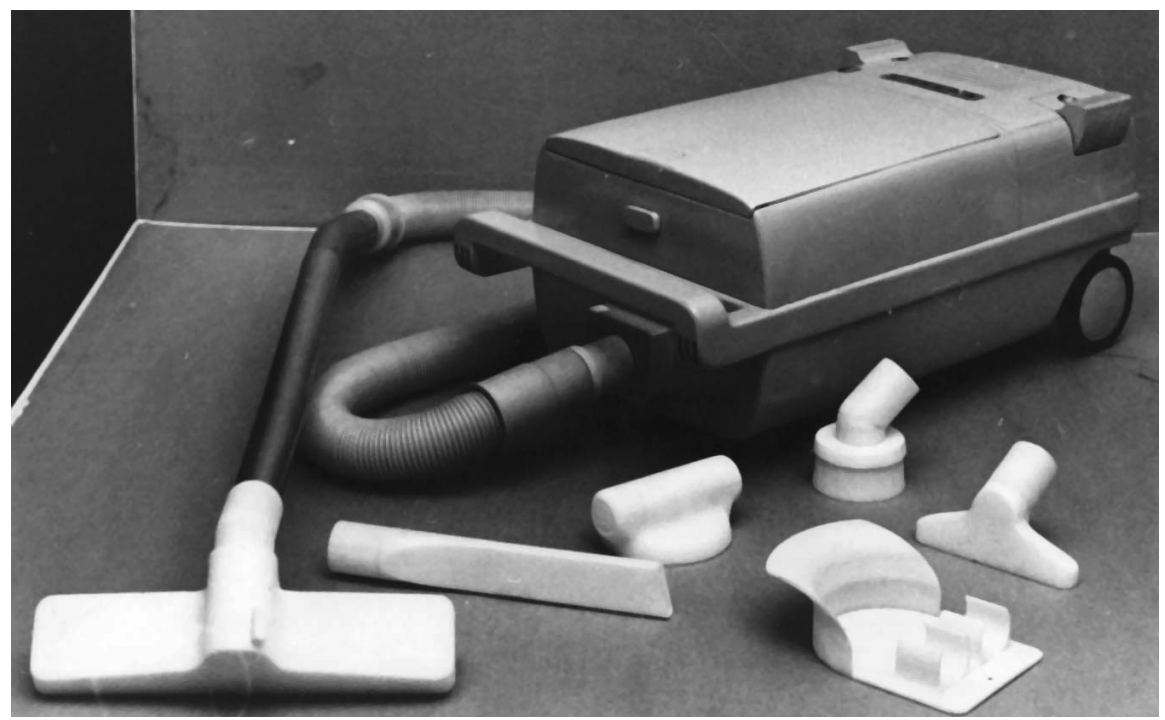

All rights reserved and permission to use the figure must be obtained from the copyright holder.

4.8 B. Korolev et al., model of vacuum cleaner Buran 7 with a set of nozzles, 1977.

come to the forefront of design professionals' vision of proper, 'spirited' living. As art historian Liudmila Andreeva noted in Dekorativnoe Iskusstvo SSSR in 1975, it was 'important that objects do not displace people and that they are liveable [uzhivchivymi']'. ${ }^{74}$ Rather than ordering things, she 
proposed sharing the domestic space with them in an ethical way, whether they be household appliances or 'rehabilitated' knick-knacks. Buran 7 would nicely integrate into a home with a grandmother's cherished chairs and old photographs, and it had the appropriate nozzles for cleaning them gently.

\section{A home is not a house but an environment}

At the same time as the Soviet government expected designers to improve the quality of consumer objects, VNIITE employees were realising that thinking in terms of separate objects was inadequate for socially responsible design. Following Tomas Maldonado, Gui Bonsiepe and Abraham Moles $^{75}$ of the Ulm School of Design (1953-68, the school that promoted interdisciplinary and socially responsible approaches to design), VNIITE designers tended to regard environments, rather than objects themselves, as ideal end products of their work. A team of Leningrad designers argued in 1973 that a singular object is the measure of an environment's order, and a designer's task is to define the qualities of objects, evaluate them in terms of compatibility, select compatible objects and harmonise them. The result would be an 'object ensemble' with distinct 'functional, technological and aesthetic characteristics'; subsequently, on a meta-structural level, such ensembles would be combined to constitute a diverse environment. ${ }^{76}$ In such a vision, a designer obviously occupied the position of a rational observer and actor who was external to the environment in question. In a similar way, Riabushin spoke of a 'living environment' (zhilaia sreda) as the main target of a designer's labour. The environment as an 'object-spatial unity' was presented here as a necessary framework for optimising the interrelations between planning, design and industrial production in the whole country, and thus overcoming the chaotic production of poor-quality, unwanted commodities. Riabushin characterised the environment as 'the material body [predmetnoe telo] of human activity' and, accordingly, argued that the designer had the power to organise the surrounding objects and materials into an integral, well-balanced environment. ${ }^{77}$ This argumentation echoes the idea of an artist as an organiser of production and everyday life that was promoted in the 1920s by such avant-garde theorists as Boris Kushner, Nikolai Tarabukin and Boris Arvatov. ${ }^{78}$

However, Riabushin's vision was not rigid: it allowed room for flexibility, variation and spontaneity in designing the environment, which would counter the alienation of human beings from the world of industrially produced objects around them. Unlike his Leningrad colleagues, Riabushin took the environment as the starting point and measure for a designer, rather than the singular object: he argued that 'integral design' must precede the design of any object. ${ }^{79}$ 
This idea progressed over the second half of the 1970s and resulted in a more complex vision of the environment. An important role in this development belongs to the Central Educational and Experimental Studio of the Artists' Union that had been functioning since 1964 as an artistic alternative to VNIITE and its orientation to the practical tasks of the planned economy. The studio, called Senezh after the lake near Moscow next to which it was located, aimed to foster the collective, creative work of designers that its founders, philosopher Karl Kantor and designer Evgenii Rozenblium, thought of as 'the cultural self-critique of industrial design'. ${ }^{80}$ For such a critique, they instrumentalised the notion of the environment. In search of an alternative to rigid city planning, Rozenblium employed a group of young architects who were knowledgeable about the latest Western critiques of modernism. ${ }^{81}$ They developed the "environmental approach' to urban planning that one of them, Andrei Bokov, later characterised as more flexible than the Soviet practice of planning and building. The environmental approach was sensitive to the dynamics of modern urban and rural life and granted equal importance to both the general and the particular. Its main method was 'cultivation' (vzrashchivanie), which relied on prognosis rather than a fixed plan, and therefore depended on 'comprehension and visualization of the nature of each specific site - the procedures very close to visual art'. ${ }^{82}$ By 'nature', Bokov meant both the natural and the built environment, a unique combination of historical urban structures and natural areas. The environmental approach developed concurrently with the Soviet intelligentsia's interest in historical legacy and preservationist activism, which influenced the work of Senezh designers in addition to those architects who wished to make modernism more open to the diversity of human needs and natural sites. ${ }^{83}$

The conceptual move away from objects and towards environments revealed the inadequacy of the modernist vision of the order of things. As the engineer and philosopher Leonid Pereverzev, an employee at VNIITE and Senezh studio, observed in 1973,

Only recently, 10-15 years ago, many artists and designers believed that the main problem of the material world was its chaos. The path towards regulation and harmonisation seemed easy: a designer should define each thing's function and find a form adequate to this function. Impeccable in theory, in practice this path was often prohibitively simplified: function was understood in a crudely utilitarian sense, while form was seen in a mechanical-constructivist sense: a chair is a prop for sitting, a suit is a cover for thermal defence of the body, and a tea service is a system of reservoirs for storing and moving liquids. A house is a machine for living. ${ }^{84}$

If in the time of the aesthetic turn such sneering allusions to Russian Constructivism and Le Corbusier's functionalism would have placed Pereverzev in the camp of the retrogrades and Stalinists of art, the tiredness of rationalist design thinking had become common sense and bon 
ton among art and design critics by the early 1970s. Moreover, whereas VNIITE designers continued to dismiss imaginative forms of household objects throughout the decade, as we have seen in the case of the Buran 7 design, the preference for old objects and the rise of 'artefactual conservatism [predmetnyi konservatizm] of grandmas and grandpas' was no longer under attack. On the contrary, these consumer choices found understanding as a legitimate reaction to 'the striving of a small group of design specialists to offer people, in a centralised manner, a ready and complete model of material environment' ${ }^{85}$ Pereverzev's text exemplifies an internal critique of VNIITE design policy and attitudes that unfolded simultaneously with the development of neodecorativism in decorative art. Both processes captured and responded to the growing popularity of antiques and rising anti-urban moods among Soviet intellectuals that were reflected in 1970s films such as Autumn by Andrei Smirnov (1974) or The Theme by Gleb Panfilov (1979).

Pereverzev argued that the repudiation of Khrushchev-era modernism was a grassroots process, initially not backed by any professional community, and labelled it 'the anti-functionalist turn'. Now, he continued, designers should take full responsibility for 'deforming and de-aestheticizing the artefactual world of their contemporaries', instead of pretending to be 'unrecognised geniuses' and shifting the blame entirely on to a stubborn industry. Rather than abandoning their ideas after frustrating negotiations with manufacturers, designers should open their eyes to recognising the hidden potentials of Soviet production. Electronics was especially promising in this respect, Pereverzev believed, because it had the capacity to provide immaterial yet informationally rich and dynamic objects, for example by using holography. ${ }^{86}$ This rhetoric reveals Pereverzev's affinity with the critique of static materiality that had also been launched in the mid-1960s by his colleagues at VNIITE. While Karl Kantor, as mentioned earlier, anticipated the 'de-artefactualisation' of socialist daily life as the radicalisation of 1920s productivism, ${ }^{87}$ architect Viacheslav Loktev, on the contrary, viewed productivism as too static to be useful for the dynamic post-war world of the late 1960s. Instead of reviving half-century-old visions, Loktev called for achieving the 'dynamic order' of things based on variation and flexibility, similarly to the environmental approach in urban planning promoted by Bokov and his colleagues. ${ }^{88}$ Thus, even if the mid-1960s reaction to rigid Soviet modernism was indeed a grassroots initiative that was not directly backed by any professional instructions, as Pereverzev believed, it was a part of an important change sweeping through different social communities - from glassblowers to philosophers to the lovers of old furniture. Therefore, the anti-functionalist turn of the mid-1960s, identified by Pereverzev, can be expanded to signify this broad, multi-sited change, and to constitute a useful conceptual counterpart to the Khrushchev-era aesthetic turn. 
Further into the 1970s, these revisions of functionalism and materiality informed the prognosis of the future domestic environment at VNIITE, in which Riabushin took a leading role. In 1970 Riabushin was contracted by the State Research Institute for Resistors and Capacitors to research the possible applications of automated search technology in the home. This research would result in a so-called 'Domestic Information Machine' (DIM) - a hardware system transmitting signals from the radio and television centres to individual homes. In his study of the DIM project, Tom Cubbin connects it to Riabushin's concept of domestic theatre, developed in the early 1970s - a system of packaged equipment that can be collapsed when not in use. Instead of definite objects, a domestic theatre offered mobile structures that could move on and off the 'stage' according to the consumer's changing needs. ${ }^{89}$ As Cubbin explains, this vision of a post-object domestic environment was generated by Kantor's advocacy of de-artefactualisation and was also influenced by the ideas of internationally famous postmodernist design and architecture groups such as the British Archigram, the Japanese Metabolists, the Viennese Haus-Rucker-Co and Italy-based futuristic furniture designers Masanori Umeda and Joe Colombo. Riabushin's colleagues Evgenii Bogdanov and Vladimir Paperny (the future author of a seminal comparative analysis of avant-gardist and Stalinist architecture ${ }^{90}$ worked on visualising the 'domestic theatre', heavily borrowing from graphic images by the Western groups. Riabushin himself carefully praised these foreign sources as offering the solution for the flexible organisation of the home. He also quoted a famous 1965 essay by the English architectural critic Reyner Banham, 'A Home is not a House', that provocatively considered modern hardware as being sufficient to generate a domestic climate without any need for a building structure. ${ }^{91}$

This speculative prognostic work on the brave new domestic environment, conducted by Riabushin's team at VNIITE's Department No. 8, could hardly have had a substantial influence on the concrete projects commissioned by the manufacturers of urgently needed household objects. Nonetheless, in the 1970s VNIITE developed a notion of the environment that could be applied to the actual processes in Soviet industry and everyday life.

\section{Design programmes}

By the late 1970s, VNIITE theorists had formulated a plan for 'design programmes' (dizain-programmy). It was based on the systemic approach to design - that is, on the vision of design as a complex system of objects, built environments, graphic elements and processes involving all these. According to the prominent VNIITE theorist Selim Khan-Magomedov, systemic design was an intellectual fashion at that time. The state's interest 
in optimising the economy, which had been recentralised by Brezhnev/ Kosygin's reforms beginning in 1965, concurred with the professional aspirations of VNIITE designers who were critical of a singular object approach. ${ }^{92}$ Like productivist theorists of the 1920s, the designers were wary of veshchizm - the fetishisation of objects - and a systemic approach offered an effective antidote. Iurii Soloviev stressed the importance of design programmes not just for optimising the variety of goods, but also for interconnecting the work of different research organisations and industries. ${ }^{93}$ This type of design targeted not just the different characteristics of consumer objects, but also the processes of their production and consumption.

The first design programme was developed by VNIITE from 1973 to 1979 through a commission from the Ministry of the Instrument Industry for the All-Union Industrial Association of Electronic Measurement Instruments (SoiuzElektroPribor). The programme, entitled EletkroMera (the abbreviation for 'electronic measurement'), embraced production, logistical and material infrastructure of the whole electrical and electronic industry. It aimed at standardising the design of all electronic instruments (more than 1,500 types) and their packaging, the standardisation of workplaces and work uniforms for engineering and technical specialists, the optimisation of logistics, and the development of corporate identity. After the preliminary test, EletkroMera would reach a national scale: the new system of material objects, visual signs and logistics would enter thirty-two factories, each staffed by roughly 20,000 workers.${ }^{94}$ In this way, as design historian Margareta Tillberg explains, EletkroMera would compete with Western companies such as Siemens and General Electrics in the world market. ${ }^{95}$ Even though only a small part of the programme was realised (though according to Vladimir Runge it still had a positive effect on the industry), ${ }^{96}$ it demonstrates VNIITE's aim of integrating different sites of production and consumption, and managing large, complex systems. Design programmes that followed in the 1980s were dedicated to the optimisation of both consumer goods (watches, domestic audio-devices, bicycles) as well as production tools (for example, equipment for healthcare institutions). ${ }^{97}$

The design programme that most directly addressed the same problem that concerned the 'domestic theatre' proponents - namely the need to mitigate the challenges of growing international consumer culture - was born in Leningrad in 1979. The LF of VNIITE assumed the task of connecting the cultures of production and consumption through the notion of recycling. Before analysing this programme in detail, an overview of the sustainability problem in the USSR is in order.

\section{Waste into profit}

While there is no question that late Soviet industrial projects were hazardous for the environment, one should be cautious about presuming 
that all social practices under state socialism were outright unsustainable. The image of state socialism as wasteful - not only literally but also symbolically - owes a lot to the Western narrative that emerged soon after the formation of the Soviet bloc and that matured around the time of its collapse. After her emigration from Hungary to the US, sociologist Zsuzsa Gille noticed the persistence of the metaphor of waste in representations of the socialist economic and political order. Gille reminiscences: 'Visual representations of state socialism invoked the image of the state socialist landscape most familiar in the West - a grey still life composed of shoddy goods; people wearing poor, idiosyncratic clothes surrounded by houses that looked like they could fall apart at any time; and piled-up garbage.'98 As she adds, Western scholars of the late 1980s and early 1990s explained the wastefulness of state socialism through the drawback of the Marxist labour theory of value that viewed natural resources as free and inexhaustible. These Western arguments and representations, however plausible, did not match Gille's memories of her youth in socialist Hungary, such as collecting paper waste and metal scrap in competition among schoolchildren, queuing in a shop to return empty glass bottles and get a deposit, using your own bags when shopping, or coping with electricity-saving campaigns or scarcities of consumer goods. ${ }^{99}$

Similar memories often emerged in my personal conversations with people who had grown up in the USSR, which suggests that thrift marked the socialist regimes as much as wastefulness. Recent historical and sociological studies have demonstrated that reuse, recycling and saving were common practices in socialist societies, both in industry and in the consumer sphere. ${ }^{100}$ Sociologists Ekaterina Gerasimova and Sofia Chuikina characterised Soviet society as a 'repair society', where objects had prolonged lifespans. As the planned economy, unlike the market economy, was not self-regulating, it underwent 'constant improvement, experiment, and mandatory anti-crisis campaigns implemented by the authorities, meaning that it was perpetually under repair'. ${ }^{101}$ Shortages of goods, typical of the socialist economy, facilitated people's intimate relationships with objects and reluctance to dispose of them. Repair techniques in Soviet society included 'fixing the item, adapting it to a secondary use, using it as material from which to make something else, redefining its symbolic status, changing the context in which it is utilised, and the like'. ${ }^{102}$ Building on these authors' arguments and on interviews with the last Soviet generation, sociologist Ol'ga Gurova suggested that the idea of disposability was barely known in Soviet culture. Coping with shortages, people constantly reused objects, or remade or exchanged them with friends and relatives (particularly children's clothes passed to younger siblings or the younger children of friends). As a result, the 'life of objects in Soviet culture was virtually endless'. ${ }^{103}$ DIY practices for prolonging this life were encouraged by the state through advice books and articles in popular journals. A 
Soviet consumer object could be repaired and reused many times before ending up in a rubbish bin, and Soviet homes could display 'rugs made of old tights and scraps, sweat pants cut up into dusters, seedlings planted in cardboard milk containers, and the like'. ${ }^{104}$ Thus, if the recycling of industrial waste from the 1970s was regulated by the special sectors of the State Committees for Planning and Provision (Gosplan and Gossnab), ${ }^{105}$ consumers, in fact, performed their own kinds of recycling, motivated by thrift and the understanding of resourcefulness as a virtue.

Gerasimova and Chuikina compare the Soviet 'repair society' to preindustrial societies, where owners developed intimate relationships with things and attributed numerous symbolic meanings to them, and where 'the material environment changed little over the life of one generation; things had permanence and could long outlive their makers and first owners'. ${ }^{106}$ However, as recent studies of recycling demonstrate, similar relationships to things were characteristic in Western industrial societies up to and, to some extent, beyond the 1950s. Refuting the generalisation that capitalist societies are always throwaway societies, Ruth Oldenziel and Heike Weber remind us that, in fact, the recycling of waste played a great role in twentieth-century social history, both in the West and beyond. While mass consumerism started in the US in the interwar period, it did not develop until the late 1950s and 1960s in most European countries, while thrift and reuse were never abandoned entirely. ${ }^{107}$ Therefore, the environmental movement of the 1970s did not mean a radical change of practices for West European consumers but a reconsideration and optimisation of habitual ones. For example, Finn Arne Jørgensen demonstrates that different forms of recycling existed in Norway throughout the twentieth century, but in the 1970s, responding to the swift rise and crisis of Western throwaway culture, the state became more involved in regulating them. ${ }^{108}$ The Soviet recycling policy developed along similar lines. While the 'repair society' in the USSR thrived in the 1930s as a result of an inefficient planned economy, ${ }^{109}$ the state only attempted to govern the recycling of household refuse towards the end of the 1970s - quite possibly relying on the Western experience. The Leningrad recycling project was not, therefore, a critical response to a throwaway culture - which never fully developed under the planned economy - but an answer to the state's campaign for tightening control over waste that it viewed as a resource. Acting as experts on the state's behalf, the designers participated in forming a new 'waste regime' - to use the term proposed by Gille. A 'waste regime' is a configuration of institutional activities related to waste - its production, representation and politics. ${ }^{110}$ The designers were responsible for the representation part: they determined society's perception of waste not as a matter of individual domestic management, but as a site of citizenship and relationship with the state.

Even though the image of wasteful socialism is in many ways true, the Soviet authorities in fact increasingly regarded the problem of waste 
as crucial throughout the 1970s. From the start of the decade, five state agencies - the State Planning Committee (Gosplan), the State Committee of the USSR for Material and Technical Supplies (Gossnab), the Central Union of Consumer Cooperatives (Tsentrosoyuz) and the ministries of the ferrous metal industry and the non-ferrous metal industry - took control of the collection, processing and delivery of waste. ${ }^{111}$ In 1975 the government founded the All-Union Institute for Secondary Resources (VIVR) within Gossnab, specifically for managing these tasks. ${ }^{112}$ This initiative was not completely alien to Soviet culture: the collection of consumer and industrial waste (mostly paper and metal scraps) for recycling had been practised in the USSR since even before the Second World War, with the twin economic and didactic purposes of educating citizens in contributing to the state's prosperity. ${ }^{113}$ However, as Birgitte Pristed explains, environmental concerns emerged within the official agenda for recycling paper from the late 1950s. ${ }^{114}$ One can suppose that a similar tendency developed with regard to other materials, such as metal and textiles.

In the 1970s industrial enterprises were obliged to take care of the recycling of the waste they produced, and the costs of recycling were included in the general plans for production costs. ${ }^{115}$ However, consumer waste was more difficult to manage. As designers expressed it, 'wasteless production' was a technical matter solved within industry, whereas 'wasteless consumption' required a complex solution. In the 1970s the task of collecting recyclable waste was shared by different organisations that lacked proper coordination. ${ }^{116}$ The administration of VIVR, responsible for solving this problem, believed that it should be done through design, and commissioned Leningrad VNIITE to develop a relevant design programme. A team of five designers from the sector of complex studies, led by the sector's head Dmitrii Kochugov, developed the concept of the programme within a year. In the report on the preliminary research, they stated that the proliferation of different bodies dealing with household waste was counterproductive: 'there are too many cooks in the kitchen'. ${ }^{117}$ However, the designers did not attempt to develop an ultimate solution to the problem and take full control over recycling - or, as they called it, VR-activity (VR for vtorichnye resursy, secondary resources). Kochugov's team admitted that the radical redesign of the recycling system required a global update of administrative, technological and personnel policy, which was beyond the designers' capacity. Therefore, the Leningrad team was careful to limit the scope of the design to adjusting the everyday habits of an average Soviet citizen in relation to the state's economic and ecological concerns. This adjustment, in turn, required a system of visual and material elements. ${ }^{118}$ To use Gille's terminology, instead of designing a new waste regime, Leningrad designers took on a more modest and manageable task: to provide the current waste regime with an effective material and informational infrastructure. 
The Leningrad design project targeted two areas: the household as a source of waste and public services that mediated between households and the recycling industry. The household, as the designers argued, was a growing source of waste due to increasing urbanisation (while the volume of production waste was, on the contrary, decreasing due to the inclusion of recycling within specific industrial processes). Unlike industrial enterprises, the population was a disorganised, 'inconvenient' partner of the state in managing resources. The two main factors in this 'inconvenience' were the wide geographic distribution of ordinary consumers and their lack of motivation to separate and collect waste. The first problem, the design project found, could be solved by creating a flexible network of recycling services; the second by finding effective means to encourage consumers to cooperate.

In contrast to the recent sociological arguments about the virtually endless life of Soviet things, ${ }^{119}$ Kochugov et al. stated that consumption 'inevitably ends with the phase when objects lose all their value for them [the consumers] because of moral or physical deterioration'. ${ }^{120}$ At this stage, things turn into waste that a consumer, naturally, tries to get rid of in the easiest way possible: throwing it all out. In the late 1970s-early 1980s technology for the industrial separation of mixed waste was still a thing of the future, so it was essential to motivate people to separate it at home. The state could do this in several ways:

1 'Citizen obligation' (grazhdanskaia obiazannost'). Similar to how industrial facilities already worked, citizens would be obliged to separate and collect waste according to special regulations. However, this approach 'would contradict the basic principles of a socialist society, whose development depends on the gradual disappearance of controlling and compulsory measures of the state and on the broad cultivation of communal forms of economy, voluntary social initiatives of the masses, and democratic social forms of administering' ${ }^{121}$ Legal compulsion had led to extremes before, such as forcing schoolchildren (or in fact their parents) to collect a monthly amount of scrap paper from old school work, with punishments if they failed to do so. Considering this, the designers considered compulsion an emergency measure, to be avoided at all costs.

2 The opposite of 'citizen obligation' was the formation of 'citizen consciousness' - the spreading of public understanding of waste separation and collection as crucially important for the ecology and economy. The Leningrad designers outlined a social stance that environmental historian Finn Arne Jørgensen later characterised as 'green citizenship': active participation in society through one's consumption habits, "by choice and/or design, often motivated by an awareness of the full life cycle of any consumer products purchased'. 
Recycling is a prime example of such green citizenship. ${ }^{122}$ While Kochugov et al. did not use this term, they believed that conscious consumption was one of the bases of a socialist society. However, they admitted that it was not sufficient to be a strong motivational force, because a full understanding of the importance of recycling required a long-term ecological education.

3 The third motivation type, which was already practised in the USSR, was material rewards, such as deposits for returning glass bottles to the grocery shop, cinema tickets or ice cream for schoolchildren who won metal-collecting competitions, or vouchers for collecting at least 20 kilos of scrap paper that could be exchanged for books from the special makulatura series. ${ }^{123}$ The Leningrad design team viewed this practice not as rewarding citizens' labour, but as re-ascribing value to things that had lost their value, resulting in the 'fetishisation of waste'. In addition, such material stimulation was based on the 'temporary' flaws of the Soviet economy and the resulting shortages of goods. An offer of certain limited goods in return for waste provoked unhealthy consumerist attitudes and, moreover, stimulated corruption and the smuggling of materials out of waste-collecting organisations. ${ }^{124}$

While in a market economy green citizenship allowed for material incentives, as Jørgensen demonstrates with the example of the state-sponsored recycling infrastructure in Norway that emerged in the 1970s, ${ }^{125}$ Soviet green citizenship was imagined as free from any mercantile interests. Voluntary ecological activity had to be encouraged not by coercion but by design: creating an effective material and informational infrastructure would smoothly integrate recycling into people's daily routine. The currently uninterested population would consider recycling only if it required minimal effort on their part.

The next report on the design programme presented waste separation and collection both as automated processes and as conscious contributions to the economy and to environmental protection. A combination of industrial and graphic design would produce what Jørgensen calls a 'recycling junction' - the point of interaction between consumer and recycling agencies, 'the place and time at which the consumer chooses to recycle or discard something'. The decision processes, as Jørgensen specifies, 'depend on more than individual values; they involve competing sets of knowledge and information, disposal infrastructures, availability of new resources and goods, and time commitments, among other factors'. ${ }^{126}$ To be functional, the Soviet recycling junction needed to adjust to the material structure of people's daily lives and simultaneously strongly affect their visual environment.

In 1981 Kochugov's team developed the first proposal for the design 
programme that now went under the name Vtormar ('Secondary material resources'). In its initial version it only targeted urban areas, but it would later be expanded, mutatis mutandis, to include rural areas as well. The basic method of Vtormar was so-called 'scenic modelling' - the imagining of possible ways for consumers to be involved in a recycling project. With this method, designers exercised an environmental approach to recycling: they drafted different environments where ordinary people could interact with waste through the mediation of material objects and visual signs. ${ }^{127}$ The key variations of these interactions were then illustrated by sketches. This totality can be divided into two categories: material objects and informational graphics.

The material means of recycling were presented through a vast array of collection bins, containers and transportation, suitable for different environments (flats, staircases with or without garbage chutes, courtyards, streets, parks, caterers, grocery shops, motor depots, etc.) and for different types of waste (scrap paper, glass, scrap metal, plastics, textiles, car tyres and bones). Various objects and items were introduced to maximally simplify consumers' contribution to the recycling system. These ranged from paper bags delivered to every household by mail for free, to large steel containers in neighbourhood courtyards, to specially equipped trucks, even to the uniforms worn by recycling service employees and souvenirs with the Vtormar logo. When citizens were receiving paper bags, having separate collectors on staircases and in courtyards, assisted by the municipal housing services and surrounded by eye-catching logos and slogans, they could easily adopt 'green' behaviour. The Vtormar objects, manufactured from recycled materials themselves, would also demonstrate how easy recycling had become. As meta-objects, they signified the resurrection of Soviet consumer objects without fetishising them as sources of profit. In this respect, Vtormar objects embodied the avant-garde idea of things as comrades and agents of social life - in this case, the agents of a waste regime. ${ }^{128}$

The informational means of recycling also echoed the concepts and aesthetics of the Russian avant-garde. Simultaneously, they demonstrated the influence of contemporary Western graphic design - for instance, the designers chose the Helvetica typeface for the logo and corporate identity, developed in 1957 by the Swiss designer Max Miedinger. ${ }^{129}$ However, the Leningraders did not just build from Western forms of corporate identity, but rather relied on the method of 'scenic' (or as they also called it 'situational') modelling. Different everyday situations mandated different degrees of public comprehension of recycling - 'VR-messages', in the terminology of Kochugov et al. An ordinary citizen at home would be exposed to VR-messages mostly through mass media, while in an airport's waiting lounge she or he might need an element of entertainment to notice the same message. Therefore, the Vtormar programme required the involvement of a diversity of information channels: not only the familiar press, 
radio and TV, but also outstanding, attention-catching elements: 'an informational game machine, an agitation bloc, or a mobile exhibition'. ${ }^{130}$ This multimedia approach again echoed the agitation and propaganda practices of the 1920s, which combined different media - from newspapers and radio to multifunctional street furniture that could combine kiosks, loudspeakers and information stands, to urban festivals. ${ }^{131}$ However, unlike the 1920s avant-garde experiments, the Vtormar programme did not transmit explicit political messages. Its main educational goal was to downplay the association of trash with dirtiness and present recycling as both a profitable and environmentally conscious activity. This new image of waste was encapsulated in rhyming slogans: Otkhody v dokhody ('Waste into profit') and Vtorichnoe - znachit otlichnoe ('Secondary means excellent'). The slogans, in turn, would enter urban environments in the form of supergraphics - a system of graphic elements in an urban space, such as banners, posters, façade decorations and street furniture. However, whereas the avant-garde supergraphics presented a striking contrast to the traditional architecture of the early Soviet cities, ${ }^{132}$ the Vtormar visuals would harmoniously integrate into their environments. The choice of green and blue referred unambiguously to the natural resources that recycling helps to preserve. The neutral character of the Helvetica typeface underscored the individualised styling of the Vtormar logo, which included two Russian letters 'R' (Cyrillic 'P'). While the diagonals of the two R-letters instilled a sense of movement that caught the eye, it also carried a symbolic meaning. The opposition of the two identical graphic elements with two different colours signified the change of a material's quality in the recycling process, while the repetition itself symbolised secondary use, thus illustrating the slogan 'Waste into profit'. ${ }^{133}$ The curved semi-oval outline of the $\mathrm{R}$ additionally alluded to the meaning of recycling as qualitative change rather than mere repetition. The Leningraders had quite possibly been inspired by the famous recycling logo from 1970 designed by American designer Gary Anderson.

As the main producer of recycling propaganda, the Kochugov team offered an interactive mobile exhibition, the main purpose of which was to stimulate 'active perception and instant challenging of one's preconceived notions and, eventually, generate conscious attitudes to the [recycling] problem in general and the delivery of secondary resources in particular'. The optimal form for such an exhibition would be an 'activity book' produced by folding screens, made from corrugated fibreboard, representing the 'expressive world of secondary resources'. Proceeding through the four parts of the exhibition - 'Consumption', 'Pollution', 'Vtormar services' and 'The results of recycling' - a visitor would absorb the state's economic and ecological objectives - a soft, implicit propaganda. The emotional effect of this 'journey' would be achieved through spatial and colour dynamics. A visitor would proceed from dark stands to a dull grey 
cube, to a 'sterile white-and-green volume' and, finally, to a vivid, colour-bursting environment. This rite de passage of sorts would place the visitor in the position of a folk hero who successfully overcomes challenges (environmental threat and economic disaster) and ends up "pleasantly discovering her capacity to make the right choice and joyfully realise this choice's multiple benefits'. ${ }^{134}$ However, because this 'right choice' would be predesigned, it would be anything but free. As the Vtormar project suggests, the freedom of consumer choice had to be sacrificed for the sake of environmental protection and sustainable economy.

In 1985-86 the Vtormar design programme led to a recycling experiment in Beltsy, the third largest city in the Moldovan Soviet Socialist Republic (with a population of 143,000). This city had a well-developed industry and transport infrastructure with a stable, heterogeneous population, and had supposedly already proved responsive to public service innovations. It was considered a convenient ground for testing the new recycling approach. The project was approved by VIVR, the administrations of secondary resources of the State Provision Committees of the USSR and Moldovan SSR, and the All-Union and Moldovan trusts of secondary resources management. Whereas the material rewards programme for paper recycling resulted in the delivery of a mere 25 per cent of paper scraps to collecting stations according to the report produced by VIVR (cited by the Kochugov team), ${ }^{135}$ the Vtormar programme promised to raise the figures by providing the population with all the earlier mentioned conveniences for separate collection of different wastes. Post officers and volunteer schoolchildren distributed paper or plastic collectors to households; some of the collection bags doubled as calendars. Differentiated waste containers were to be permanently set up at rubbish dumps (in older districts) or periodically at entrances to staircases (in the areas with high-rise buildings), as well as at different urban junctions: in parks, at bus stops, near kiosks and in department stores. These containers' colours and logos would make them stand out from the urban landscape. Additionally, the designers believed that 'their constant presence in sight will be an additional visual reminder of the scale and significance of the experiment'. ${ }^{136}$ Before integrating these everyday recycling facilities into the domestic and urban fabric, the organising institutions planned a broad advertising campaign through mass media and a city festival with the extensive use of supergraphics. ${ }^{137}$ The designers also developed special equipment for collecting stations and uniforms for collecting services employees. Kochugov's team enthusiastically anticipated the results of the Beltsy experiment, where citizens would be active participants and show their pure enthusiasm for recycling, 'unspoiled' by material incentives. However, there is currently no published or archival evidence available regarding the success - or failure - of this ambitious initiative. In any case, Vtormar never became an effective, nationwide recycling programme, and 

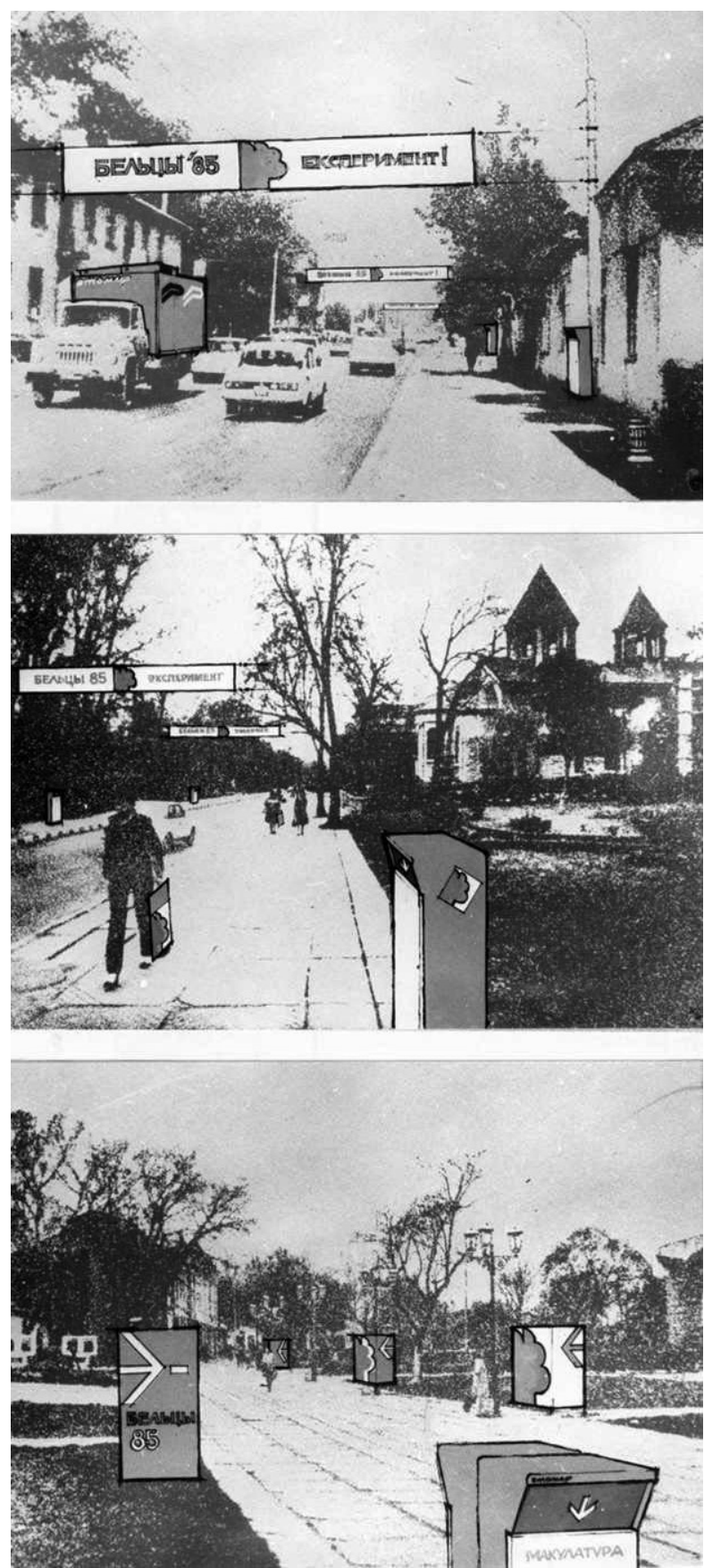

All rights reserved and permission to use the figure must be obtained from the copyright holder.

4.9 Dmitrii Kochugov et al., design programme Vtormar ('Secondary material resources'), experimental implementation, 1984. 
the approaching perestroika shifted the recycling problem to the margins of the state's agenda. Ultimately, Vtormar fell into the ranks of the many forgotten visionary projects, such as the Domestic Information Machine. That said, the idea of recycling infrastructure that was integrated yet visually striking may be of use to today's environmental activists in Russia.

\section{Conclusion}

For Soviet design professionals, the Brezhnev era was marked by active state sponsorship for a project directed at solving the twin crisis of ineffective production and frustrated consumers. The notion of the environment, born in the late 1960s out of the crisis of functionalism (the anti-functionalist turn, as design theorist Leonid Pereverzev called it), became the most promising tool for improving the material culture of the present and the future. The environmental approach to design offered a solution both to the state's goal of optimising industrial production and to the designers' interest in the legacy of the Russian avant-garde and the 1970s Western socio-political critiques of design. The disenchantment with object-based functionalism had developed in parallel with the routine design of household objects. However, the latter tended to rely on rising social values such as the diversity of tastes, interest in antiques, and the search for spiritual fulfilment in the domestic environment. Furthermore, the notion of the environment was extended to signify the problematic interaction between nature and the world of commodities. As a result, the environmental threat of consumption was recognised by the state and design professionals not only as a hazard of capitalism but also as the reality of socialist societies. This new understanding of the object-environment relationship necessitated an important design task, and recycling became an important part of VNIITE's agenda. In the late 1970s the nationwide recycling system proved to be a highly relevant topic for the new format of VNIITE's work: design programmes. Combining material and visual elements, and relying on the Russian avant-garde's legacy and contemporary Western design ideas, the Leningrad design team produced an impressive programme that revealed the broad ecological implications of a socialist household. Predictably, however, this programme proved to be too ambitious for the state of the Soviet economy at a time of changing political leadership after Brezhnev's death in 1982, and was later obscured by the urgent goals of perestroika.

\section{Notes}

1 Smirnov, Khudozhnik o prirode veshchei.

2 Smirnov uses the Russian male pronoun on, as is common in generic sentences in Russian, in the same way that masculine forms of nouns could be used as 'universal'. While the word khudozhnik (artist) does have a feminine form khudozhnitsa, 
it was used only in relation to a specific female artist. Some saw (and still see) such feminine forms as pejorative, reflecting the incompleteness of Soviet gender equality. The introduction or popularisation of feminine forms for denoting professions is still a highly contested subject in Russia.

3 Smirnov, Khudozhnik o prirode veshchei, p. 129.

4 'Industrial Design Definition History', the official website of World Design Organisation (formerly known as International Council of Societies of Industrial Design), http://wdo.org/about/definition/industrial-design-definition-history/ (accessed 6 June 2018).

5 Ibid.

6 Kushner, 'Organizatory proizvodstva'; Tarabukin, Ot mol'berta k mashine.

7 RGALI, f. 2943, op. 1, d. 2550, l. 10.

8 A. Riabushin et al., 'Tekhnicheskaia estetika I bytovaia sreda', in Iurii Soloviev et al. (eds), Khudozhestvennoe konstruirovanie bytovogo oborudovaniia (Moscow: VNIITE, 1970), p. 6.

9 Larry Busbea, 'Metadesign: Object and Environment in France, c. 1970', Design Issues 25.4 (2009), 103.

10 Cubbin, 'The Domestic Information Machine', 13.

11 Kushner presented this concept at a meeting at the Institute of Artistic Culture (Inkhuk) on 16 March 1922. The stenographic record of this presentation is in the personal archive of the architecture historian Selim Khan-Magomedov, who summarised Kushner's ideas in a chapter of his book: Khan-Magomedov, Pionery sovetskogo dizaina, pp. 251-2.

12 Tarabukin, Ot mol'berta k mashine, p. 30.

13 Kantor, Krasota i pol'za, pp. 255-76.

14 Cubbin, 'The Domestic Information Machine', 13.

15 Ibid., 15-19.

16 On consumer demand and activity, see Chernyshova, Soviet Consumer Culture in the Brezhnev Era, chs 3-7.

17 Soloviev et al. (eds), Khudozhestvennoe konstruirovanie bytovogo oborudovaniia.

18 Azrikan, 'VNIITE'.

19 Central State Archive of Scientific and Technical Documentation, St Petersburg (hereafter TsGANTD SPb), f. 146, p. 2-1, d. 78, ll. 6-7.

20 Stites, Revolutionary Dreams, pp. 155-64.

21 Ibid., p. 156.

22 Marjorie L. Hilton, 'The Invention of Soviet Advertising', in Roberts (ed.), Material Culture in Russia and the USSR, pp. 119-34.

23 S. A. Selivankin and S. V. Tarasov, Iuvelirnye izdeliia i chasy (Moscow: Ekonomika, 1967), pp. 89-90.

24 Ibid., p. 90.

25 B. G. Radchenko, Pokupateliu o chasakh (Moscow: Ekonomika, 1967), pp. 16-17.

26 TsGALI SPb, f. 266 op. 1. d. 320, ll. 41-2.

27 Piletskii, 'Pribory I mebel'.

28 Azat Romanov and Eugenia Kikodze, text for the exhibition 'Moscow Thaw', Museum of Moscow, 16 December 2016-12 April 2017.

29 Riabushin et al., 'Tekhnicheskaia estetika i bytovaia sreda', 8.

30 RGANTD, f. P-688, op. 4-1, d. 21.

31 'Kitchen Wall Clock, 1956-57', gallery label from 'Counter Space: Design and the Modern Kitchen’, MoMA, 15 September 2010-14 March 2011, www.moma.org/ collection/works/139247 (accessed 23 June 2018); Sean Lorentzen, 'The Art of Time: Max Bill and "Die gute Form", Worn \& Woud blog, 23 June 2016, http:// wornandwound.com/art-time-max-bill-die-gute-form/ (accessed 23 June 2018).

32 RGANTD, f. P-688, op. 4-1, d. 21, 1. 5. 
33 N. S. Gellershtein, 'Ergonomika - soiuznik khudozhnika-konstruktora', Tekhnicheskaia Estetika 1 (1964), 17-18.

34 Metodicheskie ukazaniia po provedeniiu ekspertizy promyshlennykh izdelii s pozitsii tekhnicheskoi estetiki (Moscow: VNIITE, 1967), 15.

35 RGANTD, f. P-688, op. 4-1, d. 21, 1. 5.

36 Pamela Popeson, 'The Perfect Kitchen Clock', Inside/Out: A MoMA/MoMA PS1 blog, 19 November 2010, www.moma.org/explore/inside_out/2010/11/19/theperfect-kitchen-clock/ (accessed 24 June 2018).

37 TsGALI SPb, f. 78, op. 4, ed. khr. 517, 1. 2.

38 The bulletin, addressed mainly to employees in industry and trade, but also to ordinary consumers, aimed to stimulate the expansion and update of goods' varieties in different regions of the USSR, and therefore emphasised new and outstanding qualities of each new commodity.

39 I. Gutman, 'Kholodil'nik 'Oka', Novye tovary 1 (1957), n.p.

40 Oldenziel and Zachmann (eds), Cold War Kitchen; Reid, "'Our Kitchen Is Just as Good": Soviet Responses to the American National Exhibition in Moscow', in Crowley and Pavitt (eds), Cold War Modern, pp. 154-62.

41 Castillo, Cold War on the Home Front, pp. 130-6, 159.

42 Narodnoe khoziaistvo SSSR v 1965 godu: statisticheskii ezhegodnik (Moscow: financy I statistika, 1965), pp. 138-9; RGANTD, f. R-688, op. 1-1, d. 85, 1. 3.

43 Narodnoe khoziaistvo SSSR v 1965 godu: statisticheskii ezhegodnik, p. 251.

44 Russian State Archive of Economy, Moscow (hereafter RGAE), f. 4372, op. 66, d. $4883,1.22$.

45 Central State Archive of Moscow (Tsentral'nyi gosudarstvennyi arkhiv Moskvy), f. 346 , op. 1, d. 4424. Cited in Chernyshova, Soviet Consumer Culture in the Brezhnev Era, p. 186.

46 Chernyshova, Soviet Consumer Culture in the Brezhnev Era, p. 189. Chernyshova refers to the following study: P. Scott, 'Consumption, Consumer Credit Cards and the Diffusion of Consumer Durables', in Francesca Carnevali and Julie Marie Strange (eds), 20th Century Britain: Economic, Cultural and Social Change, 2nd edn (London: Routledge, 2007), p. 169.

47 Helen Peavitt, Refrigerator: The Story of Cool in the Kitchen (London: Reaktion, 2017), Kindle edition, location 66.

48 RGANTD, f. R-688, op. 1-1, d. 57, l. 9; op. 1-1, d. 85, ll. 3-9.

49 TsGANTD SPb, f. 146, op. 1-4 d. 111, ll. 11-14.

50 RGANTD, f. R-688, op. 4-1, d. 52.

51 Peavitt, Refrigerator, Kindle location 735.

52 Adrian Forty, Objects of Desire (New York: Pantheon Books, 1986), p. 156.

53 RGANTD, f. R-688, op. 1-1, d. 57, l. 9; op. 1-1, d. 85, 1. 7.

54 Peavitt, Refrigerator, Kindle location 959-60.

55 RGANTD, f. R-688, op. 1-1, d. 57, 1. 9; op. 1-1, d. 85, 1. 7.

56 Piletskii, 'Pribory I mebel'.

57 RGANTD, f. R-688, op. 1-1, d. 57, l. 9; op. 1-1, d. 85, 1. 8.

58 V. I. Lenin, 'A Great Technical Achievement', in Lenin: Collected Works, vol. 19, trans. George Hanna (Moscow: Moscow Progress Publishers, 1977), pp. 61-2. Late 1950s references to this statement of Lenin are discussed in Reid, 'The Khrushchev Kitchen', 289-316.

59 RGANTD, f. R-688, op. 1-1, d. 122, 1. 40.

60 RGANTD, f. R-688, op. 1-1 d. 85 l. 3.

61 RGANTD, f. R-688, op. 1-1 d. 57, 1. 10.

62 RGANTD, f. R-688, op. 1-1 d. 57, l. 4.

63 'Pylesosy Raketa i Chaika', Novye Tovary 2 (1957), n.p.

64 Moscow Design Museum, Designed in the USSR: 1950-1989 (Berlin: Phaidon, 2018), p. 192. 
65 Ibid., p. 193.

66 Ibid., p. 10.

67 For example, the exhibition 'Moscow Thaw' at the Museum of Moscow in the winter of 2016/17 included a section 'Cosmic Theme in Soviet Design' that included a 1968 model of the vacuum cleaner Buran with a shiny surface, imitating a satellite. In his description of this section, design collector and historian Azat Romanov stressed that 'dashing contemporary forms, materials and graphic images' could be found everywhere, 'from a candy wrap or a pencil sharpener to a hydrofoil or a TV-tower'. Azat Romanov, 'Cosmic Theme in Soviet Design', wall text, Moskovskaia Ottepel: 1953-1968.

68 RGANTD, f. R-688, op. 4-1, d. 94, 1. 9.

69 RGANTD, f. R-688, op. 4-1, d. 94, 1l. 5-9.

70 RGANTD, f. R-688, op. 4-1, d. 94, 1. 9.

71 RGANTD, f. R-688, op. 4-1, d. 94, 1. 11.

72 RGANTD, f. R-688, op. 4-1, d. 94, 1. 12.

73 RGANTD, f. R-688, op. 4-1, d. 94, 1. 13.

74 L. Andreeva, 'Veshchi vokrug i my sami', Dekorativnoe Iskusstvo SSSR 7 (1975), 31.

75 On Western discussions of the design of environments, see Victor Margolin, 'Expanding the Boundaries of Design: The Product Environment and the New User', Design Issues 4.1/2 (1988), 59-64; Busbea, 'Metadesign: Object and Environment in France, c. 1970'.

76 TsGANTD SPb, f. 146, op. 2-1, d. 131, 1l. 11-12.

77 Aleksandr Riabushin, 'Sreda - mera vsekh veshchei', Dekorativnoe Iskusstvo SSSR 10 (1973), 43-6.

78 For example, Kushner, 'Organizatory proizvodstva'; Tarabukin, Ot mol'berta $k$ mashine; Arvatov, Iskusstvo i proizvodstvo.

79 Riabushin, 'Sreda - mera vsekh veshchei', 45.

80 RGALI, f. 82, op. 2, ed. khr. 2209, 1. 50.

81 Cubbin, Soviet Critical Design.

82 Andrei Bokov, 'Sredovoi podkhod 10 let spustia', Dekorativnoe Iskusstvo SSSR 6 (1986), 7.

83 Bocharnikova, 'Inventing Socialist Modern', 255-7; Cubbin, Soviet Critical Design.

84 Leonid Pereverzev, 'Chelovek-veshch-chelovek', Dekorativnoe Iskusstvo SSSR 10 (1973), 1-2.

85 Ibid., 2.

86 Ibid., 3.

87 Kantor, Krasota i pol'za, pp. 255-76.

88 Loktev, 'O dinamicheskom funktsionalizme'.

89 Cubbin, 'The Domestic Information Machine', 13.

90 Paperny, Kul'tura Dva.

91 Reyner Banham, 'A Home is not a House', Art in America 2.4 (1965), http://mindcontrol-research.net/wp-content/uploads/2016/12/4_banham_home_not_house. pdf (accessed 10 July 2018). Tom Cubbin quotes Riabushin's book which mentioned this text: A. Riabushin, Futurologiia zhilishcha za rubezhom (Moscow: VNIITE, 1973), 134; Cubbin, 'The Domestic Information Machine', 19.

92 Mark Harrison, 'Economic Growth and Slowdown', in Edwin Bacon and Mark Sandle (eds), Brezhnev Reconsidered (Basingstoke: Palgrave Macmillan), pp. 52-7; Tillberg, 'Made in the USSR', 38.

93 Iu. B. Soloviev, 'Prolemy I perspektivy sovetskogo dizaina', Tekhnicheskaia Estetika 10 (1984), 3-5.

94 Runge, Istoriia dizaina, nauki i tekhniki, pp. 263-4; West, 'CyberSovietica', pp. 179-80.

95 Tillberg, 'Made in the USSR', 36. 
96 Runge, Istoriia dizaina, nauki i tekhniki, p. 264.

97 Ibid.

98 Zsuzsa Gille, From the Cult of Waste to the Trash Heap of History: The Politics of Waste in Socialist and Postsocialist Hungary (Bloomington, IN: Indiana University Press, 2007), pp. 1-2.

99 Ibid., p. 3.

100 Paul R. Josephson, Resources Under Regimes: Technology, Environment, and the State (Cambridge, MA: Harvard University Press, 2004), pp. 186-9; Ekaterina Gerasimova and Sof'ia Chuikina, 'The Repair Society', Russian Studies in History 48.1 (2009), 58-67, doi:10.2753/RSH1061-1983480104; Ol'ga Gurova, 'The Life Span of Things in Soviet Society', Russian Social Science Review 50.4 (2009), 49-60, doi:10.1080/10611428.2009.11065356; Milena Veenis, Material Fantasies: Expectations of the Western Consumer World Among the East Germans (Amsterdam: Amsterdam University Press, 2012); Jakob Calice, 'Garbage Recycling Rhetoric in the GDR: An Environmental Historic Perspective', Trans-disciplinary Journal of Emergence 3.2 (2005), http://textfeld.ac.at/text/713/ (accessed 12 March 2018); Birgitte Beck Pristed, 'Reading and Recycling: Soviet Paper Debate and the Makulatura Books, 1974-1991', forthcoming in Russian Review.

101 Gerasimova and Chuikina, 'The Repair Society', 59.

102 Gerasimova and Chuikina, 'The Repair Society', 60.

103 Gurova, 'The Life Span of Things in Soviet Society', 58.

104 Gerasimova and Chuikina, 'The Repair Society', 68.

105 Viazheslav Deviatkin, 'Upravleniie otkhodami v Rossii: pora Ispol'zovat' otechestvennyi I zarubezhnyi opyt', Otechestvennye Zapiski 2 (2007), www. strana-oz.ru/2007/2/upravlenie-othodami-v-rossii-pora-ispolzovat-otechestven nyy-i-zarubezhnyy-opyt (accessed 14 March 2018).

106 Gerasimova and Chuikina, 'The Repair Society', 60.

107 Ruth Oldenziel and Heike Weber, 'Introduction: Reconsidering Recycling', Contemporary European History 22.3 (2013), 349, 354, doi:10.1017/S096077 7313000192.

108 Finn Arne Jørgensen, 'Green Citizenship at the Recycling Junction: Consumers and Infrastructures for the Recycling of Packaging in Twentieth-Century Norway', Contemporary European History 22.3 (2013), 499-516, doi:10.1017/ S0960777313000258.

109 Gerasimova and Chuikina, 'The Repair Society', 64.

110 Gille, From the Cult of Waste to the Trash Heap of History, pp. 34-5.

111 Staly V. Dudenkov, 'The Recycling of the Wastes of Production and Consumption as an Aspect of the Environmental Protection in the USSR', in K. Kuri (ed.), Appropriate Waste Management for Developing Countries (New York: Plenum Press, 1985), pp. 95-100.

112 Deviatkin, 'Upravleniie otkhodami v Rossii'.

113 Pristed, 'Reading and Recycling'.

114 Ibid.

115 Deviatkin, 'Upravleniie otkhodami v Rossii'.

116 Razrabotka dizain-programmemy 'Vtorichnye resursy'. Zakliuchitel'nyi otchet po teme 1969-1 (Leningrad: LF VIITE, 1980), www.waste.ru/uploads/library/ design-programmem-vr.pdf (accessed 12 November 2016).

117 Ibid., p. 5.

118 Ibid., pp. 5-37.

119 Gerasimova and Chuikina, 'The Repair Society'; Gurova, 'The Life Span of Things in Soviet Society'.

120 Razrabotka dizain-programmemy 'Vtorichnye resursy', p. 11.

121 Ibid., p. 12.

122 Jørgensen, ‘Green Citizenship at the Recycling Junction', 500. 
123 Pristed, 'Reading and Recycling'; 'Kak sobirali vtorsyr'e v SSSR', blog of the Association of St Petersburg bloggers, 2 May 2017, https://goodspb.livejournal. com/673912.html (accessed 20 March 2018).

124 Razrabotka dizain-programmemy 'Vtorichnye resursy', p. 12.

125 Jørgensen, 'Green Citizenship at the Recycling Junction'.

126 Ibid., 501.

127 TsGANTD SPb, f. 146 op. 2-2 d. 141, 1l. 5-6.

128 TsGANTD SPb, f. 146, op. 2-2, d. 141, 142. The rest of this section is based on these documents and the one cited in note 78 .

129 The classic Cyrillic version of Helvetica was developed in 1981-84 by a VNIITE designer Anatolii Kudriavtsev, www.paratype.ru/help/designers/designer.asp? code=AD_KDA (accessed 20 March 2018). I am thankful to Alyona Sokolnikova for bringing this to my attention.

130 TsGANTD SPb, f. 146 op. 2-2 d. 141, 1. 17.

131 Khan-Magomedov, Pionery sovetskogo dizaina, pp. 108-34.

132 Ibid., p. 110.

133 TsGANTD SPb, f. 146 op. 2-2 d. 141, 1. 17.

134 TsGANTD SPb, f. 146, op. 2-2, d. 143, ll. 38-9.

135 'Eksperiment Vtormar v deistvii', Tekhnicheskaia Estetika 7 (1986), 13.

136 Ibid.

137 TsGANTD SPb, f. 146, op. 2-2, d. 146, ll. 8-13. 